Prepared in cooperation with U.S. Fish and Wildlife Service

\title{
Modeling Occupancy of Rare Stream Fish Species in the Upper Cumberland and Kentucky River Basins
}

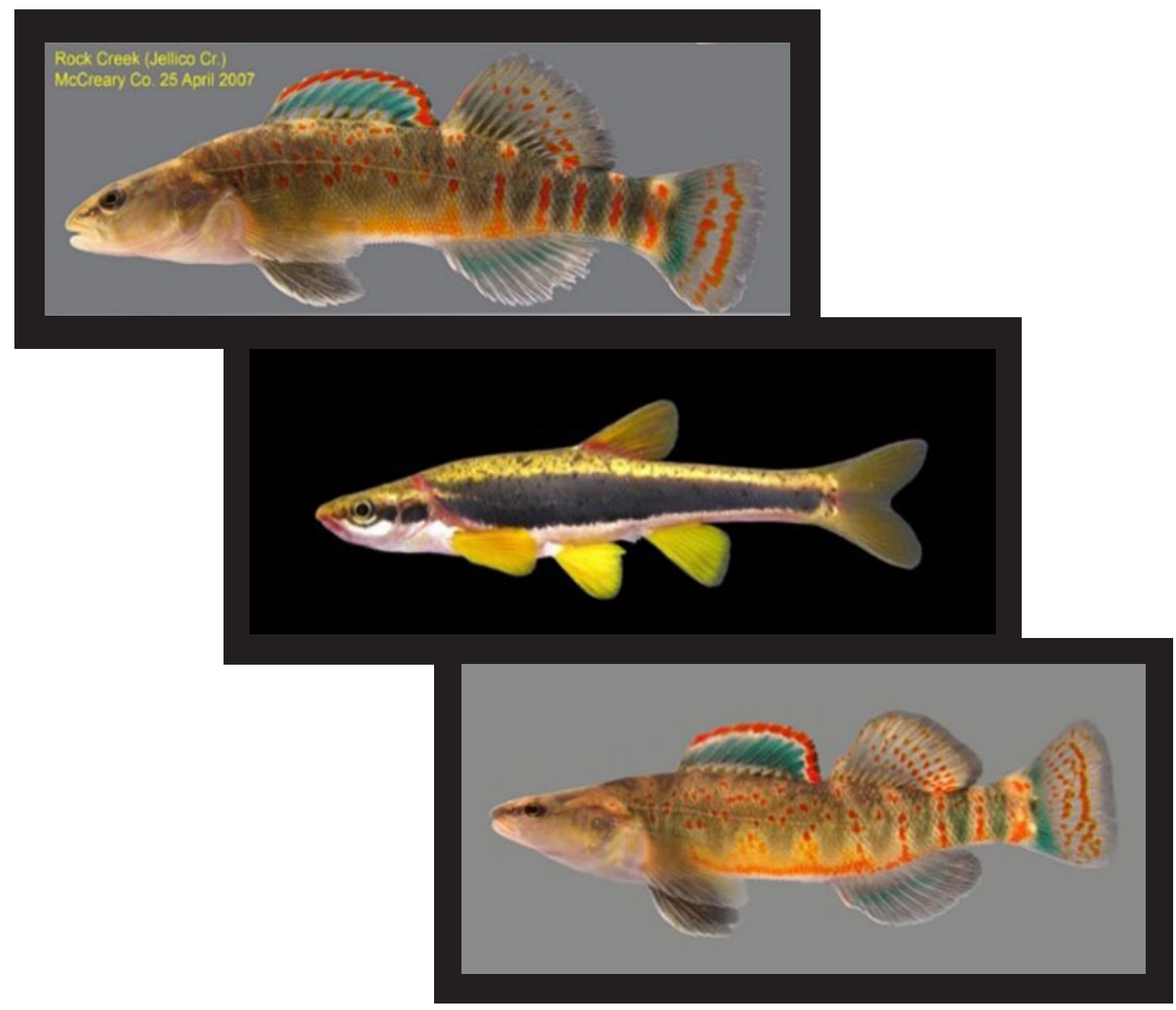

Open-File Report 2020-1100 
Focal species in this study: Cumberland arrow darter (top), blackside dace (middle), Kentucky arrow darter (bottom). Photos by Dr. Matthew Thomas, Kentucky Department of Fish and Wildlife Resources. 


\section{Modeling Occupancy of Rare Stream Fish Species in the Upper Cumberland and Kentucky River Basins}

By Nathaniel P. Hitt, Karli M. Rogers, Karmann Kessler, and Hannah Macmillan

Prepared in cooperation with U.S. Fish and Wildlife Service

Open-File Report 2020-1100 


\title{
U.S. Department of the Interior \\ DAVID BERNHARDT, Secretary
}

\author{
U.S. Geological Survey \\ James F. Reilly II, Director
}

U.S. Geological Survey, Reston, Virginia: 2020

For more information on the USGS - the Federal source for science about the Earth, its natural and living resources, natural hazards, and the environment—visit https://www.usgs.gov or call 1-888-ASK-USGS.

For an overview of USGS information products, including maps, imagery, and publications, visit https://store.usgs.gov/.

Any use of trade, firm, or product names is for descriptive purposes only and does not imply endorsement by the U.S. Government.

Although this information product, for the most part, is in the public domain, it also may contain copyrighted materials as noted in the text. Permission to reproduce copyrighted items must be secured from the copyright owner.

Suggested citation:

Hitt, N.P., Rogers, K.M., Kessler, K., and Macmillan, H., 2020, Modeling occupancy of rare stream fish species in the upper Cumberland and Kentucky River Basins: U.S. Geological Survey Open-File Report 2020-1100, 22 p., https://doi.org/10.3133/ofr20201100.

ISSN 2331-1258 (online) 


\section{Acknowledgments}

We thank Mike Compton (Office of Kentucky Nature Preserves), Michael Floyd, Peggy Shute (U.S. Fish and Wildlife Service), Matthew Thomas (Kentucky Department of Fish \& Wildlife Resources), Stephen Faulkner, Thomas O'Connell, and Daniel Fitzgerald (U.S. Geological Survey) for assistance with this research. 



\section{Contents}

Acknowledgments ……...................................................................................................................

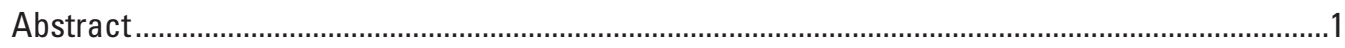

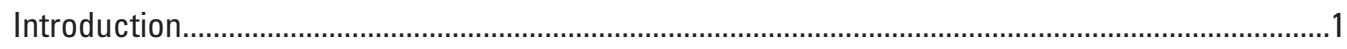

Methods

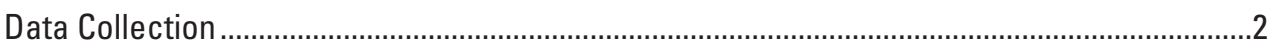

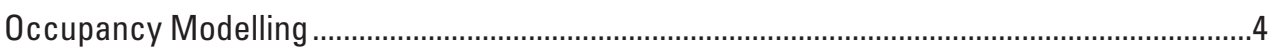

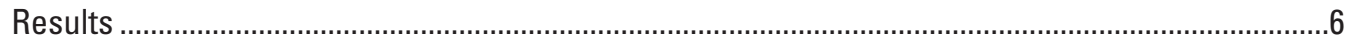

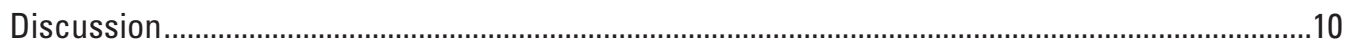

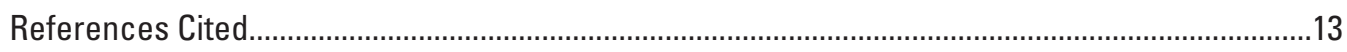

\section{Figures}

1. Photos showing focal species included in this analysis: blackside dace, Cumberland arrow darter, Kentucky arrow darter, and Cumberland darter ......................2

2. Map showing location of Cumberland and Kentucky River Basins in Virginia and Kentucky with sampling sites

3. Correlation matrix for detection-level covariates in the upper Cumberland River Basin and the upper Kentucky River Basin.

4. Correlation matrix for occurrence-level covariates in the upper Cumberland River Basin and upper Kentucky River Basin

5. Graphs showing blackside dace predicted occurrence and detection probabilities and 95-percent confidence intervals for covariates in the top three models

6. Graphs showing Cumberland arrow darter predicted occurrence and detection probabilities and 95-percent confidence intervals for covariates in the top three models

7. Graphs showing Kentucky arrow darter predicted occurrence and detection probabilities and 95-percent confidence intervals for covariates in the top three models

\section{Tables}

1. Environmental covariates for modeling species detection probability in the upper Cumberland River Basin and upper Kentucky River Basin

2. Site covariates for modeling species occurrence probability in the upper Cumberland River Basin and upper Kentucky River Basin.

3. Description of the top three occupancy models for blackside dace, Cumberland arrow darter, and Kentucky arrow darter.

4. Top model coefficients for blackside dace, Cumberland arrow darter, and Kentucky arrow darter

5. Estimated detection probability and occurrence probability for top three occupancy models for blackside dace, Cumberland arrow darter, and Kentucky arrow darter. 


\section{Conversion Factors}

International System of Units to U.S. customary units

\begin{tabular}{|c|c|c|}
\hline Multiply & By & To obtain \\
\hline \multicolumn{3}{|c|}{ Length } \\
\hline centimeter $(\mathrm{cm})$ & 0.3937 & inch (in.) \\
\hline millimeter (mm) & 0.03937 & inch (in.) \\
\hline meter $(\mathrm{m})$ & 3.281 & foot $(\mathrm{ft})$ \\
\hline kilometer (km) & 0.6214 & mile (mi) \\
\hline kilometer (km) & 0.5400 & mile, nautical (nmi) \\
\hline meter $(\mathrm{m})$ & 1.094 & yard (yd) \\
\hline \multicolumn{3}{|c|}{ Area } \\
\hline square meter $\left(\mathrm{m}^{2}\right)$ & 0.0002471 & acre \\
\hline hectare (ha) & 2.471 & acre \\
\hline square hectometer $\left(\mathrm{hm}^{2}\right)$ & 2.471 & acre \\
\hline square kilometer $\left(\mathrm{km}^{2}\right)$ & 247.1 & acre \\
\hline square centimeter $\left(\mathrm{cm}^{2}\right)$ & 0.001076 & square foot $\left(\mathrm{ft}^{2}\right)$ \\
\hline square meter $\left(\mathrm{m}^{2}\right)$ & 10.76 & square foot $\left(\mathrm{ft}^{2}\right)$ \\
\hline square centimeter $\left(\mathrm{cm}^{2}\right)$ & 0.1550 & square inch $\left(\mathrm{ft}^{2}\right)$ \\
\hline square hectometer $\left(\mathrm{hm}^{2}\right)$ & 0.003861 & section ( 640 acres or 1 square mile) \\
\hline hectare (ha) & 0.003861 & square mile $\left(\mathrm{mi}^{2}\right)$ \\
\hline square kilometer $\left(\mathrm{km}^{2}\right)$ & 0.3861 & square mile $\left(\mathrm{mi}^{2}\right)$ \\
\hline \multicolumn{3}{|c|}{ Volume } \\
\hline cubic meter $\left(\mathrm{m}^{3}\right)$ & 6.290 & barrel (petroleum, 1 barrel = 42 gal) \\
\hline liter $(\mathrm{L})$ & 33.81402 & ounce, fluid (fl. oz) \\
\hline liter $(\mathrm{L})$ & 2.113 & pint $(p t)$ \\
\hline liter $(\mathrm{L})$ & 1.057 & quart (qt) \\
\hline
\end{tabular}

Temperature in degrees Celsius $\left({ }^{\circ} \mathrm{C}\right)$ may be converted to degrees Fahrenheit $\left({ }^{\circ} \mathrm{F}\right)$ as follows: ${ }^{\circ} \mathrm{F}$ $=\left(1.8 \times{ }^{\circ} \mathrm{C}\right)+32$.

Temperature in degrees Fahrenheit $\left({ }^{\circ} \mathrm{F}\right)$ may be converted to degrees Celsius $\left({ }^{\circ} \mathrm{C}\right)$ as follows: ${ }^{\circ} \mathrm{C}$ $=\left({ }^{\circ} \mathrm{F}-32\right) / 1.8$.

\section{Datum}

Vertical coordinate information is referenced to North American Vertical Datum of 1988 (NAVD 88).

Horizontal coordinate information is referenced to the North American Datum of 1983 (NAD 83).

Elevation, as used in this report, refers to distance above the vertical datum. 


\title{
Modeling Occupancy of Rare Stream Fish Species in the Upper Cumberland and Kentucky River Basins
}

\author{
By Nathaniel P. Hitt, Karli M. Rogers, Karmann Kessler, and Hannah Macmillan
}

\section{Abstract}

Biological conservation often requires an understanding of how environmental conditions affect species occurrence and detection probabilities. We used a hierarchical framework to evaluate these effects for several Appalachian stream fish species of conservation concern: Chrosomus cumberlandensis (BSD; blackside dace), Etheostoma sagitta (CAD; Cumberland arrow darter), and Etheostoma spilotum (KAD; Kentucky arrow darter). Etheostoma susanae (Cumberland darter) also is present in the study area but was too rare to model in this analysis. In this study, conducted by the U.S. Geological Survey in cooperation with the U.S. Fish and Wildlife Service, fish and habitat data were collected from 205 randomly selected stream sites in the upper Cumberland and Kentucky River Basins (120 and 85 sites, respectively) of Kentucky and Tennessee. Sites were sampled with 10 spatial replicates ( 2 meter $\times 5$ meter electrofishing zones) to enable estimation of detection probabilities and environmental effects. The best models (that is, lowest Akaike information criterion scores) showed the effects of agriculture (negative) on occurrence of BSD and stream conductivity (negative) on occurrence of CAD and KAD. These effects were statistically more important than measures of basin area, elevation, and substrate size. Conductivity and agriculture showed nonlinear effects on species occurrence, and effects of conductivity were more precise above 400 microsiemens per centimeter than below this threshold. Models incorporated detection-level effects of electrofishing time (positive), flow velocity (negative), sand substrate (positive), and gravel/cobble substrate (negative). Models accounting for detection of BSD estimated occupancy rates similar to the observed proportion of occupied sites (0.10), but the best-supported models for CAD and KAD increased expected occupancy by about 4 percent for each species (from 0.17 to 0.21 for CAD and from 0.07 to 0.11 for KAD). Results of this study provide new inferences for modeling stream fish occurrence and detection processes and highlight the importance of continued monitoring and assessment of rare fish species in Appalachian headwater streams.

\section{Introduction}

Biological conservation often requires an understanding of environmental controls on species occurrence and detection probabilities (MacKenzie and others, 2002). Chrosomus cumberlandensis (Blackside dace; BSD), Etheostoma sagitta (Cumberland arrow darter; CAD), Etheostoma susanae (Cumberland darter; CD), and Etheostoma spilotum (Kentucky arrow darter; KAD) (fig. 1) are high-priority species because they involve Endangered Species Act (ESA) conservation planning by the U.S. Fish and Wildlife Service (FWS). The U.S. Geological Survey (USGS) conducted this study in cooperation with the FWS to evaluate environmental predictors of species occurrence while jointly modeling the detection process in a hierarchical framework.

BSD is a headwater fish species endemic to the upper Cumberland River Basin in Tennessee and Kentucky (Starnes and Starnes, 1978; FWS, 1987), with recent expansions into the Kentucky River Basin in Kentucky and the Clinch and Powell River Basins in Virginia (Skelton, 2013). It inhabits small upland streams characterized by low turbidity and fine substrates, and low conductivity levels (Starnes and Starnes, 1981; Eisenhour and Strange, 1998; Black and others, 2013a, 2013b; Hitt and others, 2016). Prior research identified conductivity thresholds associated with reduced BSD abundance at about 240 microsiemens per centimeter $(\mu \mathrm{S} / \mathrm{cm})$ (Black and others, 2013a) and about $340 \mu \mathrm{S} / \mathrm{cm}$ (Hitt and others, 2016). BSD was listed as a threatened species under the ESA in 1987 (FWS, 1987). A recovery plan was developed in 1988 (FWS, 1988), and the FWS continues conservation planning for this species (for example, FWS, 2015a).

$\mathrm{CAD}$ and KAD also are endemic to the study area, with CAD restricted to the upper Cumberland River Basin (FWS, 2012) and KAD restricted to the upper Kentucky River Basin (FWS, 2010a). These closely related species are distinguished by genetic and morphological differences (Kuehne and Bailey, 1961). Both species inhabit moderate- to high-gradient headwater streams and are obligate invertivores; adult diets include larval mayflies and other invertebrates (Thomas, 2007, 2008; FWS, 2010a, 2012). Both species also apparently have been extirpated from some locations. Rangewide surveys conducted over the last several decades have not detected CAD in 43 of 128 historically inhabited streams (34 percent) (FWS, 2015b) 


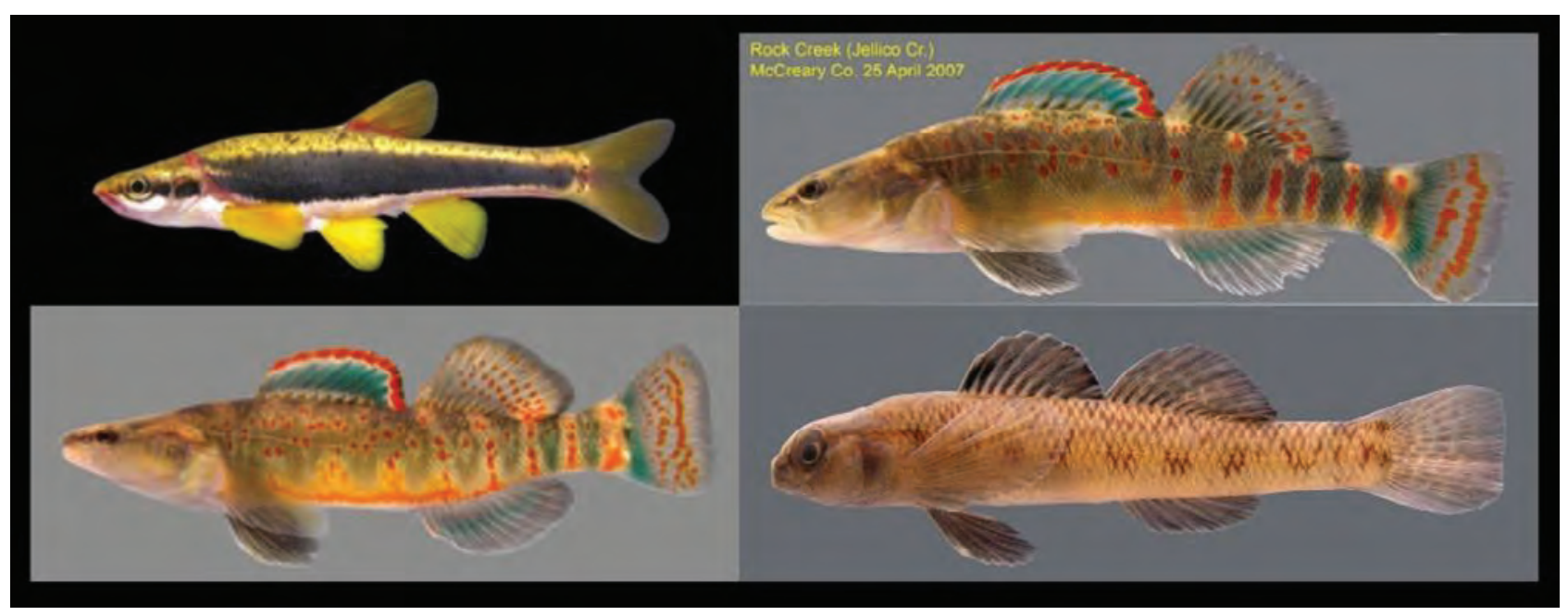

Figure 1. Focal species included in this analysis: blackside dace (top left), Cumberland arrow darter (top right), Kentucky arrow darter (bottom left), and Cumberland darter (bottom right). Photos by Dr. Matthew Thomas, Kentucky Department of Fish and Wildlife Resources.

and have not detected KAD in 36 of 74 historically inhabited streams (49 percent) (FWS, 2016). In part based on these survey data, the FWS determined CAD did not constitute a threatened species under the ESA (FWS, 2015b), but KAD did (FWS, 2016). Genetic analysis further indicated effects of recent isolation and fragmentation of KAD populations (Blanton and others, 2019) that exacerbates local extirpation risks (Fagan, 2002).

$\mathrm{CD}$ is also an endemic species within the upper Cumberland River Basin, but it has a much smaller range than BSD or CAD. Known occurrences are limited to 14 sites within 12 streams (FWS, 2010b). Ecological requirements of the species are not fully understood (FWS, 2019), but the species has been observed in streams with width ranging from 4 to 9 meters $(\mathrm{m})$ and within pools and shallow runs (O’Bara, 1991; Thomas, 2007). Their diet is probably like that of a closely related species (Etheostoma nigrum, Johnny darter) (FWS, 2011) and consists primarily of benthic macroinvertebrate larvae (Etnier and Starnes, 1993). Based on its geographic rarity and threats from degraded water quality and physical habitat, $\mathrm{CD}$ was recognized as an endangered species under the ESA in 2011 (FWS, 2011).

This report presents applied hierarchical modeling techniques to estimate environmental effects on species occurrence while modeling their detection probabilities. Imperfect detection of individuals may bias predicted occurrence rates (MacKenzie and others, 2002), and this potential problem is widely recognized for interpretation of species survey data (Bailey and others, 2014), including for the focal species (see FWS, 2016). The objectives of the study were to (1) model species occurrence and detection probabilities from environmental data and (2) estimate the potential importance of the detection process by comparing model predictions that account for detection against the observed proportion of occupied sites.

\section{Methods}

\section{Data Collection}

Fish and habitat data collected from 205 stream sites in the upper Cumberland River Basin (CU) and upper Kentucky River Basin (KE) in the southeastern United States were evaluated (fig. 2; appendix table 1.1). The landscape of the study area is characterized by highly dissected forested watersheds of the Cumberland Plateau physiographic region. Land use includes mining, forestry, and agricultural development with some urbanization in lower elevations. The $\mathrm{CU}$ study area is upstream from Cumberland Falls, and the KE study area is upstream from a series of locks and dams managed by the U.S. Army Corps of Engineers near Lexington, Ky.

Stream sampling was conducted by State and Federal wildlife biologists led by Mike Compton (Office of Kentucky Nature Preserves, OKNP) and Michael Floyd (FWS) during summer base-flow conditions in 2012, 2013, and 2015. CU sites were sampled in 2012 and $2015(\mathrm{n}=120)$, and KE sites were sampled in $2013(\mathrm{n}=85)$. Site locations were selected at random to facilitate interpretation of results across the study area. Sampling occurred between June and September each year, and most sites were sampled during August.

Sampling was conducted using spatial replicates (quadrats) to model the detection process (Charbonnel and others, 2014). Within each site, 10 quadrats were sampled using a systematic randomized design to represent available mesohabitat types (pool, riffle, run). Quadrats measured $2 \mathrm{~m}$ x $5 \mathrm{~m}$ with the long side parallel to stream flow and were separated by a minimum of $5 \mathrm{~m}$. Backpack electrofishing techniques were used to collect all fish within each quadrat (Reynolds and Kolz, 2012) using a Smith-Root LR24 backpack electrofishing unit with dipnets at 200-350 volts, 60 megahertz, and 15-20 percent duty cycle. Blocknets were not used. Captured fish 


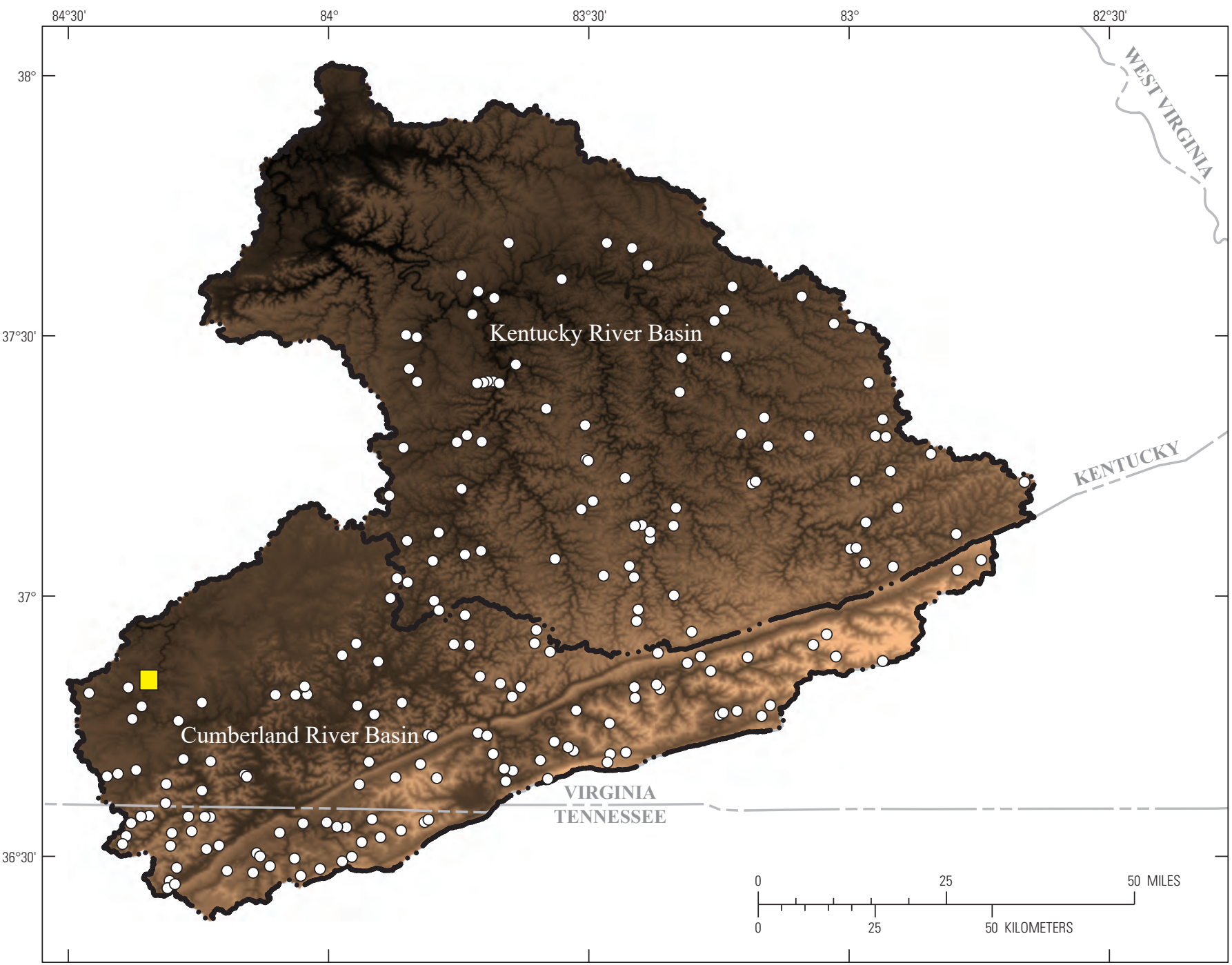

Base from ESRI, 2020

Hydrology from U.S. Geological Survey, National Hydrography Dataset, 2020

Digital elevation data from U.S. Geological Survey, EROS, 2020

WGS 1984 Web Mercator Projection, North American Datum of 1983
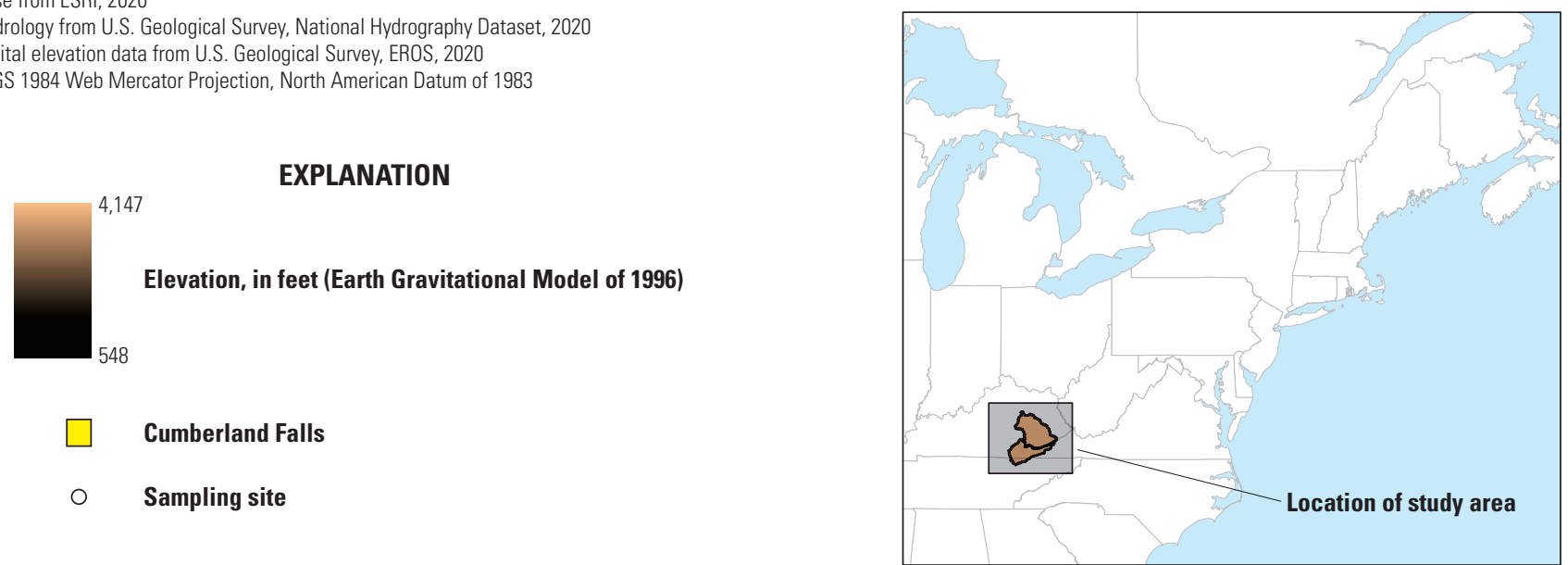

Figure 2. Location of Cumberland and Kentucky River Basins in Virginia and Kentucky with sampling sites. Sampling sites are shown as points and are listed in appendix table 1.1. 
were identified to species, counted, and released downstream after each quadrat was sampled. Sampling proceeded in an upstream direction.

Environmental covariates were measured in each quadrat (table 1), including measures of sampling effort (electrofishing time), flow velocity, stream depth, and substrate size. Substrate size categories followed Wentworth (1922) with pebble, gravel, and cobble categories combined. Stream depth and substrate size class were measured at the corners and center of each quadrat (five samples). Flow velocity was estimated visually and scored on a scale of 1 (no flow) to 4 (fast flow), following Albanese and others (2007). A total of 2,050 quadrats was sampled in the study area, including 1,200 samples in the $\mathrm{CU}$ area (120 sites) and 850 samples in the KE area ( 85 sites).

Site-level covariates include measures of water quality, stream volume, and land use (table 2). Conductivity was measured with a calibrated YSI Professional Plus multiparameter meter prior to fish sampling. We calculated elevation, upstream basin size, and stream gradient from $30-\mathrm{m}$ digital elevation models with a geographic information system (ESRI Arc Hydro tools). Land cover was expressed as the percent of upstream watershed area classified as forest, agriculture, barren land, or developed land as defined by the 2016 version of the National Land Cover Database (see Wickham and others, 2014).

\section{Occupancy Modelling}

The R package "unmarked" version 0.13-2 (Fiske and Chandler, 2011) was used to model species detection and occurrence probabilities in a hierarchical framework as

$$
\begin{aligned}
& z_{i} \sim \operatorname{Bernoulli}\left(\Psi_{i}\right) \\
& y_{i j} z_{i} \sim \operatorname{Bernoulli}\left(z_{i} p_{i j}\right)
\end{aligned}
$$

where

$$
\begin{aligned}
& z_{i} \begin{array}{c}
\text { is the state variable defining the presence } \\
\text { or absence of BSD, CAD, or KAD } \\
\text { within site } i,
\end{array} \\
& \Psi_{i}\left(p s i_{i}\right) \quad \begin{array}{l}
\text { is the probability of species presence } \\
\text { within site } i,
\end{array} \\
& p_{i j} \quad \begin{array}{c}
\text { is the probability of species detection in } \\
\text { quadrat } j \text { within site } i, \text { and }
\end{array} \\
& y_{i j} \quad \begin{array}{c}
\text { is the observed presence or absence of the } \\
\text { target species in quadrat } j \text { within site } i .
\end{array}
\end{aligned}
$$

Model (1) represents the process of species occurrence among sites, and model (2) represents the process of detec-

\begin{tabular}{|c|c|c|c|c|c|c|}
\hline Covariate & Code & Unit & Basin & Mean & SD & Range \\
\hline \multirow[t]{2}{*}{ Electrofishing time } & $\mathrm{dET}$ & Second & $\mathrm{CU}$ & 66 & 22 & $6-182$ \\
\hline & & & $\mathrm{KE}$ & 66 & 20 & $18-171$ \\
\hline \multirow[t]{2}{*}{ Stream depth } & dSD & Meter & $\mathrm{CU}$ & 0.15 & 0.13 & $0.01-1.00$ \\
\hline & & & $\mathrm{KE}$ & 0.10 & 0.11 & $0.01-0.84$ \\
\hline \multirow[t]{2}{*}{ Flow velocity } & $\mathrm{dFV}$ & Index & $\mathrm{CU}$ & 1.9 & 0.6 & $1.0-4.0$ \\
\hline & & & $\mathrm{KE}$ & 2.1 & 0.5 & $1.0-4.0$ \\
\hline \multirow[t]{2}{*}{ Fine substrates } & $\mathrm{dFI}$ & Percent & $\mathrm{CU}$ & 9 & 18 & $0-100$ \\
\hline & & & $\mathrm{KE}$ & 4 & 11 & $0-100$ \\
\hline \multirow[t]{2}{*}{ Sand substrates } & dSA & Percent & $\mathrm{CU}$ & 16 & 22 & $0-100$ \\
\hline & & & $\mathrm{KE}$ & 14 & 21 & $0-100$ \\
\hline \multirow[t]{2}{*}{ Gravel/cobble substrates } & $\mathrm{dGC}$ & Percent & $\mathrm{CU}$ & 61 & 32 & $0-100$ \\
\hline & & & $\mathrm{KE}$ & 58 & 33 & $0-100$ \\
\hline \multirow[t]{2}{*}{ Boulder substrates } & $\mathrm{dBO}$ & Percent & $\mathrm{CU}$ & 7 & 14 & $0-80$ \\
\hline & & & $\mathrm{KE}$ & 6 & 12 & $0-80$ \\
\hline \multirow[t]{2}{*}{ Bedrock substrates } & $\mathrm{dBE}$ & Percent & $\mathrm{CU}$ & 8 & 20 & $0-100$ \\
\hline & & & $\mathrm{KE}$ & 19 & 32 & $0-100$ \\
\hline
\end{tabular}
tion within a quadrat when a species is present in a given site. Within each site, the sequence of observed presence and absence records across quadrats represents a detection history with a likelihood contingent on true presence or absence $(z)$. Percent variables and continuous variables with arcsine square-root and ln-transformations, respectively, were

Table 1. Environmental covariates for modeling species detection probability in the upper Cumberland River Basin and upper Kentucky River Basin. Samples were observed at the quadrat level (that is, 10 quadrats per site).

[CU, Cumberland River Basin, $\mathrm{n}=1,200$; KE, Kentucky River Basin, $\mathrm{n}=850$. Codes are indexed with "d" to indicate detection-level covariates in subsequent tables and figures. SD, standard deviation] 
Table 2. Site covariates for modeling species occurrence probability in the upper Cumberland River Basin and upper Kentucky River Basin.

[Covariates were observed at the site level. CU, Cumberland River Basin, n=120; KE, Kentucky River Basin, n=85. Codes are indexed with "o" to indicate occurrence-level covariates in subsequent tables and figures. $\mu \mathrm{S} / \mathrm{cm}$, microsiemens per centimenter; $<$, less than; SD, standard deviation]

\begin{tabular}{|c|c|c|c|c|c|c|}
\hline Covariate & Code & Units & Basin & Mean & SD & Range \\
\hline \multirow[t]{2}{*}{ Conductivity } & $\mathrm{oCO}$ & $\mu \mathrm{S} / \mathrm{cm}$ & $\mathrm{CU}$ & 401 & 360 & $15-2,171$ \\
\hline & & & $\mathrm{KE}$ & 473 & 484 & $29-2,175$ \\
\hline \multirow[t]{2}{*}{ Basin area } & $\mathrm{oBA}$ & Hectare & $\mathrm{CU}$ & 3007 & 6756 & $103-37,907$ \\
\hline & & & $\mathrm{KE}$ & 1471 & 2789 & $189-14,617$ \\
\hline \multirow[t]{2}{*}{ Elevation above sea-level } & $\mathrm{oEL}$ & Meter & $\mathrm{CU}$ & 391 & 91 & $282-769$ \\
\hline & & & $\mathrm{KE}$ & 308 & 54 & $219-488$ \\
\hline \multirow[t]{2}{*}{ Barren land cover } & $\mathrm{oBR}$ & Percent & $\mathrm{CU}$ & $<1$ & 1 & $0-6$ \\
\hline & & & $\mathrm{KE}$ & 1 & 3 & $0-15$ \\
\hline \multirow[t]{2}{*}{ Forest land cover } & $\mathrm{oFO}$ & Percent & $\mathrm{CU}$ & 83 & 16 & $26-100$ \\
\hline & & & $\mathrm{KE}$ & 82 & 17 & $13-100$ \\
\hline \multirow[t]{2}{*}{ Agricultural land cover } & oAG & Percent & $\mathrm{CU}$ & 2 & 5 & $0-31$ \\
\hline & & & $\mathrm{KE}$ & 3 & 7 & $0-44$ \\
\hline \multirow[t]{2}{*}{ Developed land cover } & $\mathrm{oDE}$ & Percent & $\mathrm{CU}$ & 3 & 4 & $0-29$ \\
\hline & & & $\mathrm{KE}$ & 5 & 3 & $0-18$ \\
\hline \multirow[t]{2}{*}{ Fine substrates } & $\mathrm{oFI}$ & Percent & $\mathrm{CU}$ & 9 & 13 & $0-75$ \\
\hline & & & $\mathrm{KE}$ & 4 & 5 & $0-22$ \\
\hline \multirow[t]{2}{*}{ Sand substrates } & oSA & Percent & $\mathrm{CU}$ & 16 & 16 & $0-94$ \\
\hline & & & $\mathrm{KE}$ & 14 & 15 & $0-65$ \\
\hline \multirow[t]{2}{*}{ Gravel/cobble substrates } & $\mathrm{oGC}$ & Percent & $\mathrm{CU}$ & 61 & 23 & $2-98$ \\
\hline & & & $\mathrm{KE}$ & 58 & 23 & $6-98$ \\
\hline \multirow[t]{2}{*}{ Boulder substrates } & $\mathrm{oBO}$ & Percent & $\mathrm{CU}$ & 7 & 8 & $0-42$ \\
\hline & & & $\mathrm{KE}$ & 6 & 7 & $0-37$ \\
\hline \multirow[t]{2}{*}{ Bedrock substrates } & $\mathrm{oBE}$ & Percent & $\mathrm{CU}$ & 8 & 14 & $0-64$ \\
\hline & & & $\mathrm{KE}$ & 19 & 26 & $0-90$ \\
\hline
\end{tabular}

transformed, and all covariates were scaled to a mean of 0 and standard deviation of 1 . Logit link functions were used to relate covariates to $p s i$ and $p$ on a $0-1$ probability scale.

This modeling structure provides a hierarchical framework because the observed data $(y)$ are modeled jointly with a detection process and a higher-level occupancy process. The underlying Bernoulli probability distributions assume three conditions: (1) there are only two possible outcomes (species presence or absence and species detection or non-detection), (2) species occurrence or detection in one sample unit does not affect occurrence or detection in others, and (3) the true occurrence state $(z)$ does not change during the period of data collection (Bailey and others, 2014). The rapid collection of quadrat-level data in the current study (that is, sampled within a single day) gives high confidence for satisfying the latter condition. We assumed that electrofishing did not affect the spatial distribution of fish among quadrats (see "Discussion" section).
The dataset was split by basin for modeling species occupancy, yielding 120 sites (1,200 quadrats) for analysis of BSD and $\mathrm{CAD}$, and 85 sites (850 quadrats) for analysis of KAD. First-order combinations of all covariates at the detection and occurrence levels were evaluated using Akaike Information Criterion scores (AIC) scores to identify the best performing models for each species (117 models per species). Model goodness-of-fit was evaluated using bootstrapped chi-squared statistics with 1,000 samples; all possible combinations of covariates were not evaluated because higher-order models generally lacked sufficient goodness-of-fit for interpretation. The expected probability of detection and occurrence ( $p$ and $p s i$ ) was evaluated for top-performing models with covariates effects held at mean-effect levels. 
Occupancy of Rare Stream Fish in the Upper Cumberland and Kentucky River Basins

\section{Results}

The fish dataset includes 16,717 individuals, of which the focal species constituted a small fraction. A total of 96 individual BSD were observed within 23 quadrats across 12 sites in the CU study area (naive occupancy $=0.10$ ). In sites where BSD were observed, they were detected on average in 1.9 quadrats (19 percent) with a maximum observed presence within 5 quadrats in one site (DOW02036606 in table 1.1). A total of 52 individual CAD were observed within 37 quadrats across 20 sites in the CU study area (naive occupancy $=0.17$ ). As with BSD, CAD were observed on average in 1.9 quadrats (19 percent) within sites where they were detected, and the maximum observed presence was 5 quadrats in one site (DOW02013601 in table 1.1). Thirteen KAD were observed within 10 quadrats across six sites within the KE study area (naive occupancy $=0.07$ ). In sites where KAD were observed, they were detected on average in 1.7 quadrats (17 percent) with a maximum observed presence within 3 quadrats in one site (DOW04052401 in table 1.1). CD was observed in only one site (13 individuals within 5 quadrats); therefore, it was excluded from further analysis because it lacked enough observations for modeling.

Environmental covariates measured at the quadrat level exhibited substantial variation (table 1) and similar patterns of correlation within the CU and KE study areas (fig. 3). Sampling effort as indexed by electrofishing time (dET in table 1) ranged from 6 to 182 seconds per quadrat, and mean values were equivalent across study areas (66 seconds; table 1). Quadrat depths ranged from $0.01 \mathrm{~m}$ to $1.00 \mathrm{~m}$ (table 1) with a grand mean of $0.13 \mathrm{~m}$. Substrates in both study areas were primarily gravel/cobble (61 percent and 58 percent in $\mathrm{CU}$ and $\mathrm{KE}$, respectively; table 1) and secondarily sand (16 percent and 14 percent in CU and KE, respectively; table 1). Bedrock was more abundant in KE sites than in CU sites (19 percent and 8 percent, respectively; table 1).

Electrofishing time increased with quadrat depth (fig. 3). Flow velocity was inversely related to the percent fine substrates and positively related to percent gravel/cobble substrates within quadrats (fig. 3). Percent sand and gravel/cobble substrates were inversely related, and gravel/cobble substrates were inversely related to the percent bedrock (fig. 3). Detection covariates showed similar correlations in both study areas, but flow velocity generally showed stronger relations to substrate size in $\mathrm{CU}$ than in $\mathrm{KE}$, and bedrock showed stronger relations within $\mathrm{KE}$ than $\mathrm{CU}$ (fig. 3).

Site-level covariates included measures of water quality, stream volume, land use, and substrate size (table 2). Stream conductivity ranged from 15 to $2,175 \mu \mathrm{S} / \mathrm{cm}$, and mean values were not different between study areas $(t=-1.2, p=0.25)$. Conductivity decreased with forest cover and increased with barren land cover in both study areas (fig. 4). By comparison, developed land cover showed relatively weak correlations with conductivity (fig. 4), indicating the importance of sulfates from surface mine runoff rather than chlorides from road salts (Cormier and others, 2013). Conductivity was positively related to the percent gravel/cobble and negatively related to the percent sand within CU sites but not KE sites (fig. 4). Conductivity increased with the percent fine substrates in $\mathrm{KE}$ but not in CU (fig. 4).

Upstream basin areas range from 103 hectares (ha) to nearly 38,000 ha (table 2) and were larger on average in CU than in $\mathrm{KE}(t=2.3, p=0.02)$. Site elevations ranged from 282 $\mathrm{m}$ to $769 \mathrm{~m}$ (table 2) and were higher on average in CU than in $\mathrm{KE}(t=8.1, p<0.001)$. Forest dominated land cover in both study areas ( 83 percent and 82 percent in $\mathrm{CU}$ and $\mathrm{KE}$, respectively), whereas agriculture and developed areas constituted less than 5 percent of land cover in all cases (table 2). Barren land was rare in the land-cover dataset, accounting for 1 percent of the KE basins on average and less than 1 percent of the CU basins on average (table 2).

Basin area and elevation generally showed stronger correlations with land use and substrate size among CU sites than among KE sites (fig. 4). Percent agriculture and developed areas were positively associated, and each showed negative associations with percent forest cover. The percent barren land was positively associated with developed land in CU but not in KE (fig. 4). Elevation showed a positive correlation with percent bedrock in CU but a negative correlation in $\mathrm{KE}$ (fig. 4). Percent agriculture showed a positive association with percent fine substrate in CU but not in KE (fig. 4).

Bootstrapped chi-squared statistics indicated sufficient goodness-of-fit for the top three models for each species (appendix table 1.2). The top three models (that is, lowest AIC scores) for BSD (table 3) show a negative effect of agriculture on occurrence probability and detection-level effects of electrofishing time (positive), flow velocity (negative), and gravel/cobble substrate (negative) (table 4; fig. 5). Uncertainty of the predicted effect of agriculture generally decreased with increasing agricultural land cover (that is, decreasing confidence intervals with increasing covariate values; fig. 5). Conductivity exhibited a negative relation with BSD occurrence but was not included in the top three models.

A single model best described CAD occupancy given the observed data (that is, AIC cumulative weight $=1$ for the top model; table 3). This model showed a negative effect for stream conductivity on occurrence probability and simulated the detection process with a positive effect for electrofishing time (table 4; fig. 6). The predicted (negative) effect of conductivity on CAD occurrence probability was more precise at greater than mean values than less than mean values in the CU study area (about $400 \mu \mathrm{S} / \mathrm{cm}$ threshold; table 2). In contrast, predicted effects of barren land cover (negative) and forest cover (positive) on CAD occurrence probability showed decreasing precision at low and high covariate values (fig. 6).

The top three models for KAD (table 3 ) included negative effects of conductivity and barren land cover on occurrence probability (table 4; fig. 7). Covariates on KAD detection probability included effects of sand substrate (positive) and electrofishing time (positive). As with CAD, uncertainty in the predicted (negative) effect of conductivity on KAD occurrence diminished with increasing conductivity values. In contrast, 


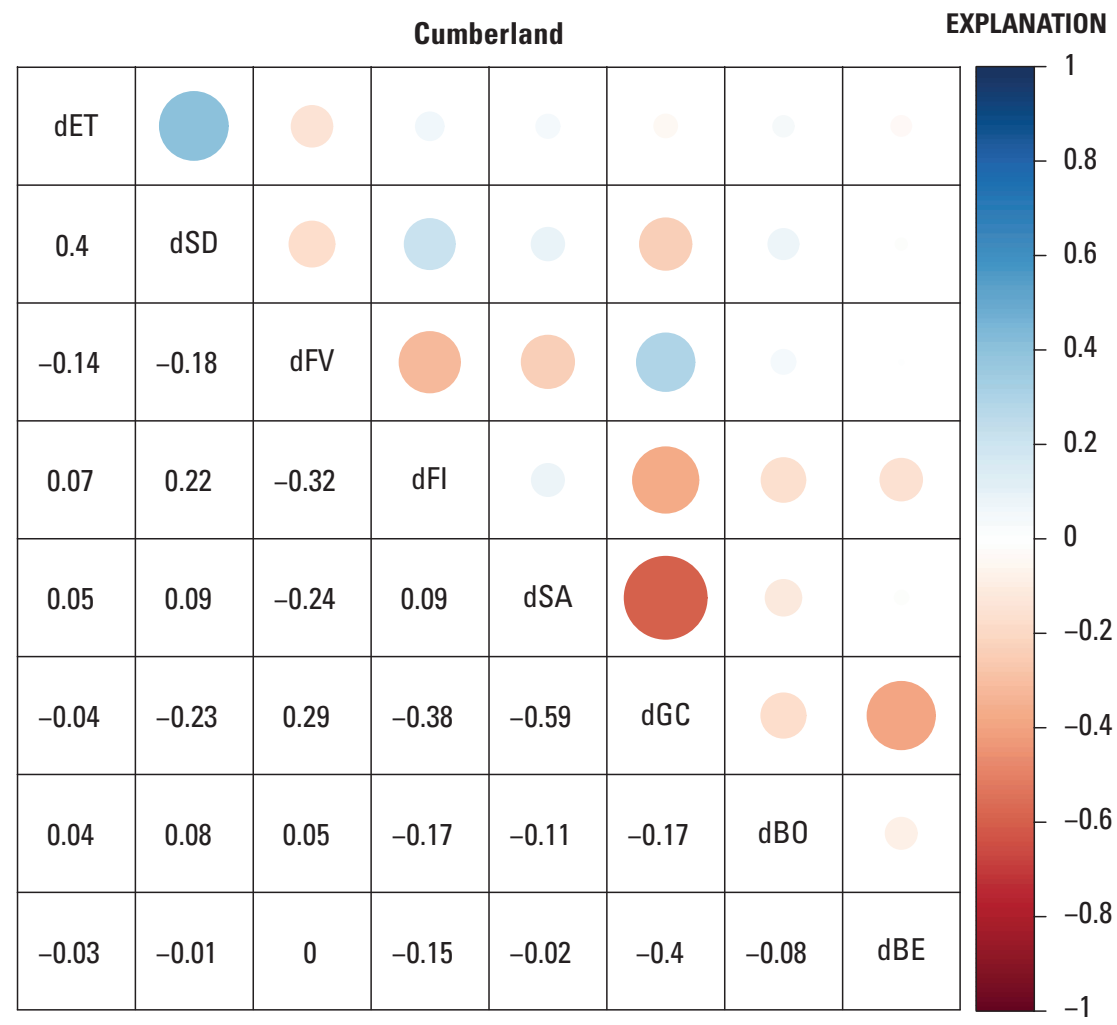

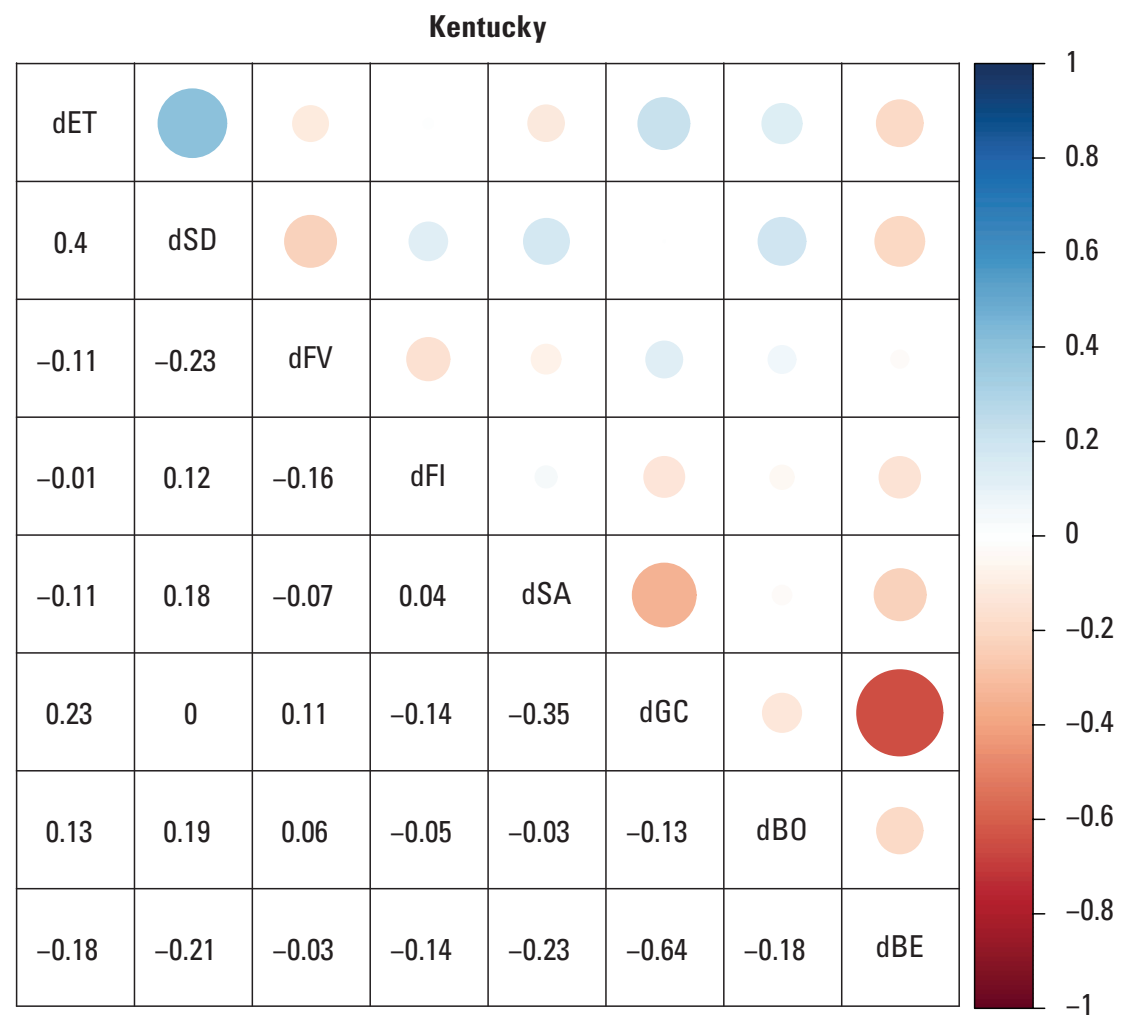

Figure 3. Correlation matrix for detection-level covariates in the upper Cumberland River Basin and the upper Kentucky River Basin. Cumberland River Basin, n=1,200 quadrats; Kentucky River Basin, $n=850$ quadrats. Lower diagonal cells give Spearman correlation coefficients, and upper diagonal cells represent correlation direction (color) and magnitude (circle size). Codes are given in table 1, and study sites are shown in figure 2 . 


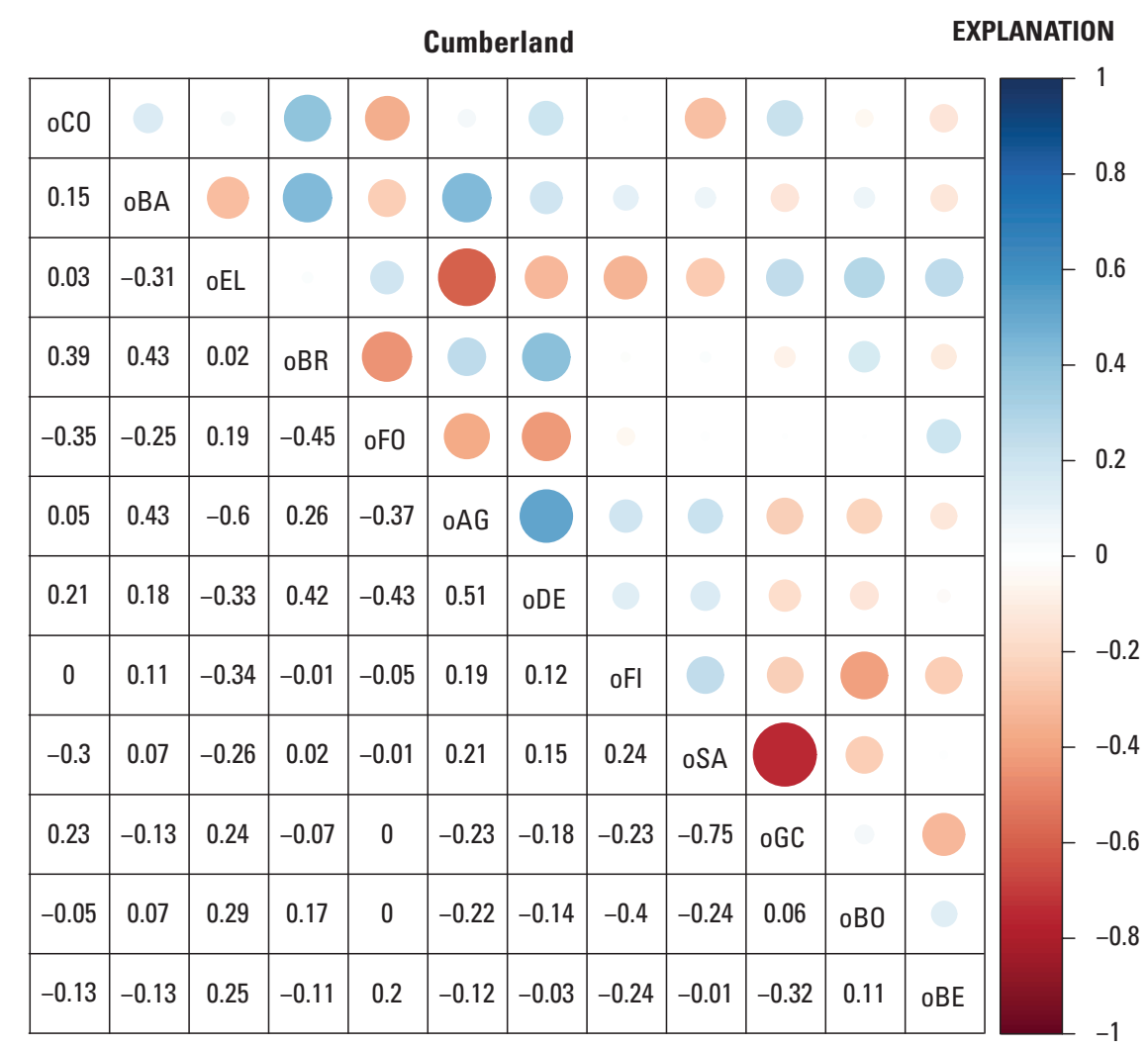

Kentucky

\begin{tabular}{|c|c|c|c|c|c|c|c|c|c|c|c|}
\hline oCO & & & & & & & & & & & \\
\hline 0.06 & oBA & 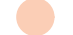 & 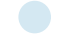 & & & & & & & & \\
\hline 0.19 & -0.25 & $\mathrm{oEL}$ & & & & & & & & & \\
\hline 0.59 & 0.18 & 0.27 & oBR & & & & & & & & \\
\hline-0.48 & -0.07 & 0.06 & -0.57 & oFO & & & & & & & \\
\hline-0.22 & 0.14 & -0.61 & -0.12 & -0.23 & $\mathrm{oAG}$ & & & & & & \\
\hline 0.04 & -0.02 & 0.02 & 0.28 & -0.31 & 0.42 & oDE & & & & & \\
\hline 0.25 & 0.1 & 0.06 & 0.08 & -0.13 & 0 & 0.1 & oFI & & & & \\
\hline 0.18 & 0 & 0.19 & 0.17 & -0.19 & -0.19 & 0.15 & 0.26 & oSA & & & \\
\hline 0.09 & -0.03 & 0.14 & 0.13 & -0.07 & 0.07 & 0.26 & 0.08 & -0.29 & $\mathrm{oGC}$ & & \\
\hline-0.07 & 0.13 & 0.08 & 0.17 & -0.13 & -0.06 & 0.02 & -0.2 & 0.01 & 0.05 & oBO & \\
\hline-0.21 & -0.15 & -0.35 & -0.3 & 0.12 & 0.12 & -0.29 & -0.26 & -0.37 & -0.6 & -0.22 & $\mathrm{oBE}$ \\
\hline
\end{tabular}

Figure 4. Correlation matrix for occurrence-level covariates in the upper Cumberland River Basin, $n=120$, and upper Kentucky River Basin, $n=85$. Lower diagonal cells give Spearman correlation coefficients, and upper diagonal cells represent correlation direction (color) and magnitude (circle size). Codes are given in table 2, and study sites are shown in figure 2. 
Table 3. Description of the top three occupancy models for blackside dace, Cumberland arrow darter, and Kentucky arrow darter.

[Covariates for detection probability $(\beta p)$ and occurrence probability $(\beta p s i)$ are defined in table 1 and table 2 . The relative difference in Akaike Information Criterion scores ( $\triangle \mathrm{AIC}$ ), AIC weights (AICw), cumulative AIC weights (AICwc), and number of parameters (nP) are given for each model]

\begin{tabular}{|c|c|c|c|c|c|c|}
\hline Model & $\beta p$ & $\beta p s i$ & $\mathrm{nP}$ & $\triangle A I C$ & AICw & AICwc \\
\hline \multicolumn{7}{|c|}{ Blackside dace } \\
\hline 1 & $\mathrm{dET}$ & oAG & 4 & 0.00 & 0.10 & 0.10 \\
\hline 2 & $\mathrm{dFV}$ & $\mathrm{oAG}$ & 4 & 0.77 & 0.07 & 0.18 \\
\hline 3 & $\mathrm{dGC}$ & $\mathrm{oAG}$ & 4 & 1.44 & 0.05 & 0.23 \\
\hline \multicolumn{7}{|c|}{ Cumberland arrow darter } \\
\hline 1 & $\mathrm{dET}$ & $\mathrm{oCO}$ & 4 & 0.00 & 1.00 & 1.00 \\
\hline 2 & $\mathrm{dET}$ & $\mathrm{oBR}$ & 4 & 17.94 & 0.00 & 1.00 \\
\hline 3 & $\mathrm{dET}$ & $\mathrm{oFO}$ & 4 & 18.48 & 0.00 & 1.00 \\
\hline \multicolumn{7}{|c|}{ Kentucky arrow darter } \\
\hline 1 & $\mathrm{dSA}$ & $\mathrm{oCO}$ & 4 & 0.00 & 0.20 & 0.20 \\
\hline 2 & $\mathrm{dSA}$ & $\mathrm{oBR}$ & 4 & 2.01 & 0.07 & 0.27 \\
\hline 3 & $\mathrm{dET}$ & oCO & 4 & 3.06 & 0.04 & 0.31 \\
\hline
\end{tabular}

Table 4. Top model coefficients for blackside dace, Cumberland arrow darter, and Kentucky arrow darter.

[Coefficients are identified in table 3. Cells show standard errors (SE) and type-1 error rates (p) from standardized z-scores. $<$, less than]

\begin{tabular}{|c|c|c|c|c|c|}
\hline Level & Covariate & Estimate & SE & $z$ & $p$ \\
\hline \multicolumn{6}{|c|}{ Blackside dace } \\
\hline \multirow[t]{2}{*}{ Occurrence } & Intercept & -2.16 & 0.45 & -4.79 & $<0.001$ \\
\hline & $\mathrm{oAG}$ & -1.15 & 0.72 & -1.61 & 0.108 \\
\hline \multirow[t]{2}{*}{ Detection } & Intercept & -1.97 & 0.34 & -5.88 & $<0.001$ \\
\hline & $\mathrm{dET}$ & 0.76 & 0.30 & 2.53 & 0.011 \\
\hline \multicolumn{6}{|c|}{ Cumberland arrow darter } \\
\hline \multirow[t]{2}{*}{ Occurrence } & Intercept & -1.33 & 0.44 & -3.05 & 0.002 \\
\hline & $\mathrm{oCO}$ & -2.21 & 0.70 & -3.14 & 0.002 \\
\hline \multirow[t]{2}{*}{ Detection } & Intercept & -2.81 & 0.31 & -9.16 & $<0.001$ \\
\hline & $\mathrm{dET}$ & 1.41 & 0.28 & 4.96 & $<0.001$ \\
\hline \multicolumn{6}{|c|}{ Kentucky arrow darter } \\
\hline \multirow[t]{2}{*}{ Occurrence } & Intercept & -2.07 & 0.99 & -2.10 & 0.036 \\
\hline & $\mathrm{oCO}$ & -2.59 & 1.91 & -1.36 & 0.175 \\
\hline \multirow[t]{2}{*}{ Detection } & Intercept & -3.32 & 0.67 & -4.94 & $<0.001$ \\
\hline & $\mathrm{dSA}$ & 0.74 & 0.28 & 2.68 & 0.007 \\
\hline
\end{tabular}

the predicted effect of barren land cover on KAD occurrence became less precise at high values, indicating that conductivity is a more important predictor in this regard (fig. 7).

Estimated occurrence probabilities for BSD in the top three models were similar to the naive occupancy rate (0.10), and estimated detection probabilities ranged from 0.123 to 0.170 (table 5). Estimated occurrence probability for CAD was 0.209 in the top model, an increase of 4.2 percent from the naive occupancy rate of 0.167 (table 5), and detection probability was 0.057 in the top model for this species. Estimated occurrence probabilities for KAD ranged from 0.029 to 0.112 in the top three models, and detection probabilities ranged from 0.035 to 0.071 in the top three models (table 5). Greater detection probabilities were estimated for BSD than CAD or $\mathrm{KAD}$ in the top three models for each species: the maximum estimated detection probabilities for CAD (0.062) and KAD $(0.071)$ were less than the minimum detection probability for BSD (0.123) (table 5). 


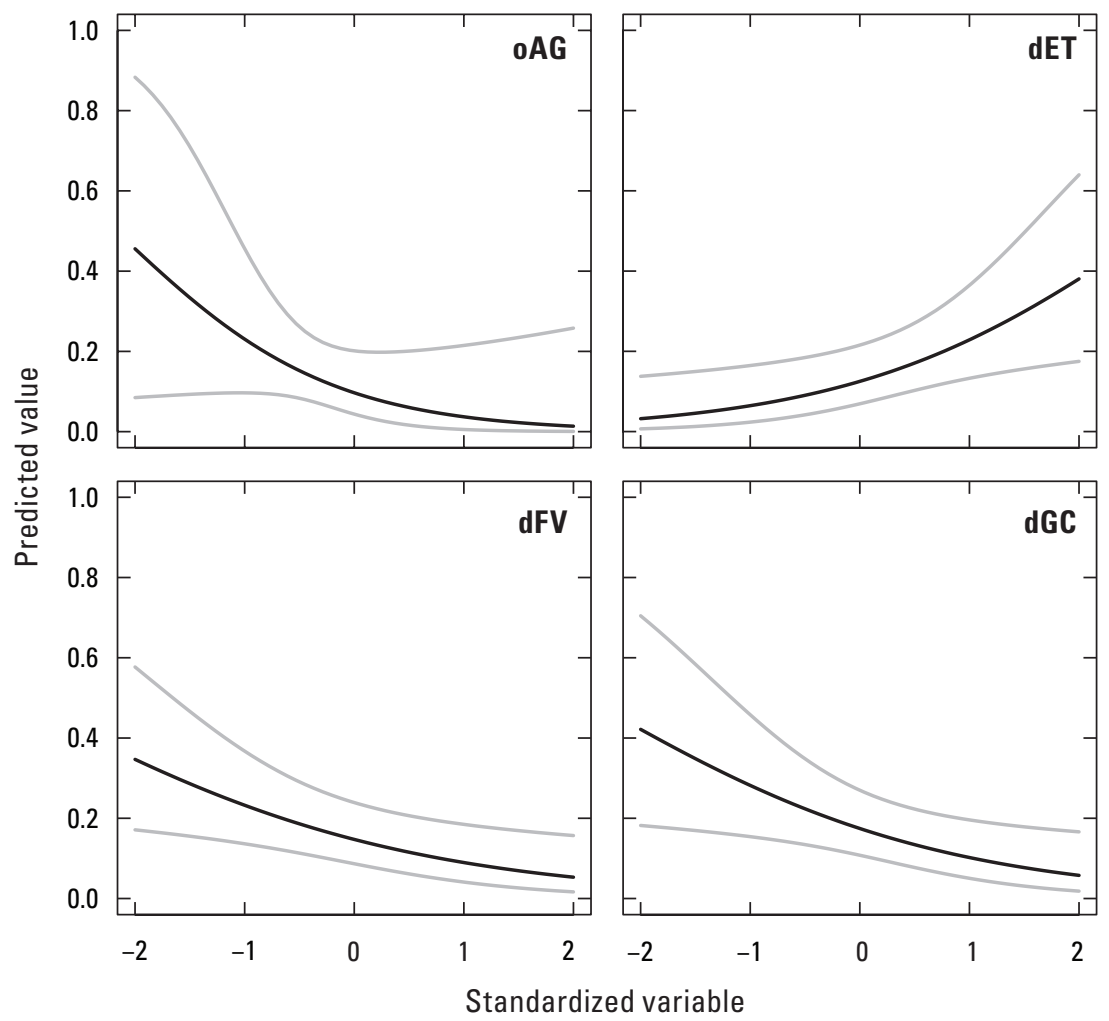

Figure 5. Blackside dace predicted occurrence and detection probabilities (black lines) and 95-percent confidence intervals (grey lines) for covariates in the top three models. Top three models are described in table 3. Covariates for occurrence ("o") and detection ("d") probabilities are defined in tables 1 and 2.

\section{Discussion}

Our analysis provides several inferences for monitoring and assessment of rare stream fishes in Appalachia. We showed that (1) quadrat-based spatial replicates can provide a useful framework for modeling stream fish occupancy; (2) sampling effort, flow velocity, and substrate size can affect species detection probabilities; (3) agriculture decreased occurrence probability for BSD, and conductivity decreased occurrence probabilities for CAD and KAD; (4) predicted effects of conductivity and agriculture became more precise as their values increased; and (5) maximum potential occupancy rates (that is, accounting for imperfect detection) were relatively low in all cases, highlighting the importance of continued monitoring and assessment of these rare stream fish species.

The best-performing models for CAD and KAD included negative effects of conductivity on species occurrence (table 4), and similar effects have been observed from independent datasets in the study area (Black and others, 2013b; Hitt and others, 2016) and elsewhere in Appalachia (Palmer and others, 2010; Hitt and Chambers, 2014; Merovich and others, in press). Conductivity was clearly the most important covariate to model CAD occurrence (that is, AIC cumulative weight $=1.0$; table 3 ). Conductivity was also included in the best model for KAD, but other variables were closer in their performance for KAD than for CAD (table 3). However, the next-best models for KAD included barren land cover (table 3, fig. 7), which is correlated with stream conductivity (fig. 3) and therefore may represent the same underlying mechanisms. Even though stream volume and temperature are primary determinants of stream fish distributions (Burton and Odum, 1945; Sheldon, 1968; Vannote and others, 1980), our indices of stream volume (basin area) and stream temperature (elevation) were unimportant in occurrence models relative to the overriding effect of conductivity.

Analysis contributed a new inference on conductivity: the predicted effects became more precise as observed conductivity values increased (fig. 6 and fig. 7). Specifically, predicted effects on CAD occurrence were more precise at greater than the mean observed value within the $\mathrm{CU}$ area (about $400 \mu \mathrm{S} / \mathrm{cm}$ ) than below this threshold. This pattern is consistent with the wedge-shaped relation between abundance and conductivity reported previously for KAD (Hitt and others, 2016), implying a limiting effect of water quality at high conductivity values and other limiting effects at low conductivity values (see Schmidt and others, 2012). Moreover, conductivity showed nonlinear relations to $\mathrm{CAD}$ and KAD occurrence such that models predicted more change at less than mean conductivity values than at greater than mean conductivity (fig. 6 and fig. 7). For instance, the steepest changes in predicted occurrence were near the conductivity benchmark established by the U.S. Environmental Protection Agency (EPA) for protection of aquatic life downstream from mining operations in Appalachia (300 $\mu \mathrm{S} / \mathrm{cm}$; EPA, 2011). Predicted effects of conductivity on CAD and KAD were consistent with the hypothesis that conductivity affects growth and survival of invertivorous fishes by altering the benthic macroinvertebrate prey base available for consumption (see Hitt and others, 2016). Moreover, we attribute observed conductivity effects to sulfates from mining activity rather than chlorides from road salts (Cormier and others, 2013) because conductivity was weakly related to developed land but strongly related to "barren" land associated with surface mining (fig. 4).

Agriculture was more important than conductivity for modeling BSD occurrence in this analysis (table 3, table 4) even though their occurrence was limited to low conductivity sites. Because agriculture is more prevalent in lower elevation sites (fig. 4), unmeasured effects of water temperature or other conditions that vary by elevation may influence the observed effect of agriculture in these models. Nonetheless, agriculture was associated with increasing fine substrates and decreasing 


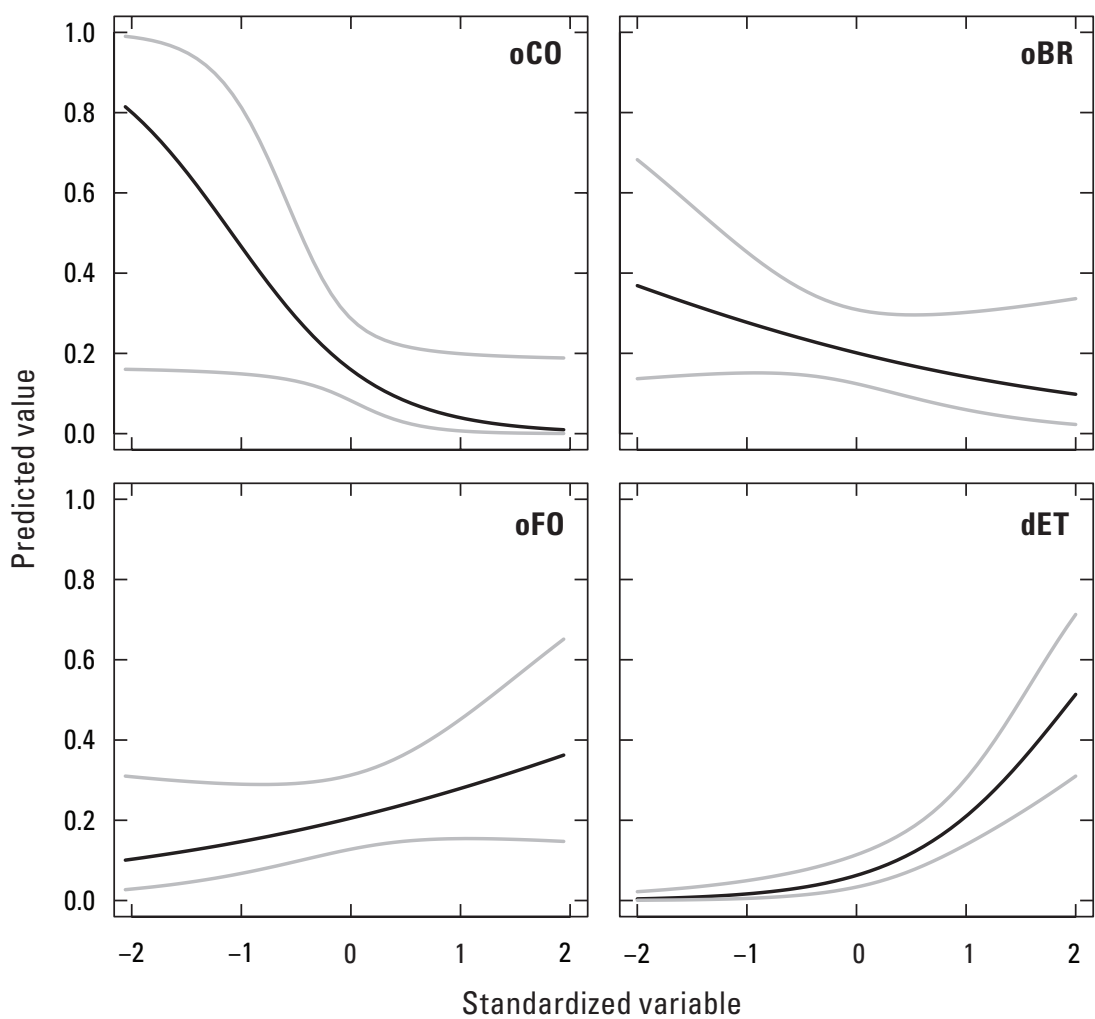

Figure 6. Cumberland arrow darter predicted occurrence and detection probabilities (black lines) and 95-percent confidence intervals (grey lines) for covariates in the top three models. Top three models are described in table 3. Covariates for occurrence ("o") and detection ("d") probabilities are defined in table 1 and table 2.

gravel/cobble substrates in the CU study area (fig. 4), and the negative effects of turbidity and siltation on BSD populations are well known (FWS, 1987). Similar agricultural effects were reported for Percina oxyrhynchus (sharpnose darter) in the upper Kentucky River Basin (Hopkins and Roush, 2013). BSD spawning is often associated with spawning mounds constructed by Semotilus atromaculatus (creek chub) (Mattingly and Black, 2013), and such nest associations can enable long-term persistence of fish species in agriculturally affected streams (Hitt and Roberts, 2012), which indicates the presence of other mechanistic effects of land use besides siltation and egg mortality. Although agriculture was not included in the top three models for CAD or KAD (table 3), it was included for models ranked 12 of 117 for CAD (top 10 percent) and 42 of 117 for KAD (top 36 percent) (results not shown). All potentially interactive effects were not evaluated (owing to higherorder models lacking sufficient goodness-of-fit), but we expect combined effects of land use as shown for benthic macroinvertebrate communities (Merriam and others, 2011) and a BSD congener in Virginia (Chrosomus sp. cf. saylori, Clinch dace) (Moore and others, 2017).

Our estimated detection probabilities ranged from 0.035 (KAD) to 0.170 (BSD) (table 5); these values are comparable to other rare stream fishes in the southeastern United States.
For example, Pteronotropis welaka (bluenose shiner) detection rates ranged from 0.03 to 0.08 (Albanese and others, 2007), and the detection rate for Percina aurolineata (goldline darter) was 0.20 (Albanese and others, 2013) using seine hauls as spatial replicates. Electrofishing and snorkeling surveys also revealed low detection rates for Erimystax insignis (blotched chub) in southern Appalachian streams (0.11 and 0.09, respectively; Albanese and others, 2011). In contrast, common stream fish species in this region can show detection rates of nearly 90 percent (for example, Albanese and others, 2007).

Higher detection probabilities were found for $\mathrm{BSD}$ than $\mathrm{KAD}$ or CAD (table 5); this may be due to differences in local abundance. BSD showed greater mean abundance than $\mathrm{CAD}$ or $\mathrm{KAD}$ at the site level $(8.0,2.6$, and 2.2 fish per occupied site, respectively), consistent with prior research (Black and others, 2013a; Hitt and others, 2016). Likewise, BSD showed greater densities at the quadrat level than CAD or $\operatorname{KAD}(4.2,1.4$, and 1.3 fish per occupied quadrat, respectively), and fish density therefore may be related to the detection process (see Royle and Nichols, 2003). Future studies on the focal species therefore may benefit by limiting quadrat samples to targeted microhabitats rather than sampling all available habitats as implemented in this study.

We found that sampling effort (that is, electrofishing time) increased detection rates for all species (table 3), as expected. However, the precision of the predicted effects was greater for $\mathrm{CAD}$ than $\mathrm{KAD}$ (that is, confidence intervals for dET in fig. 6 and fig. 7), whereas BSD showed an intermediate response (fig. 5). The results therefore underscore the importance of sampling effort for rare species detection, as shown previously (Green and Young, 1993). We further note that the effect of electrofishing effort was not simply a function of observed density because BSD was most abundant but exhibited an intermediate response to electrofishing effort (fig. 5). Instead, the observed effect of electrofishing time in our study may indicate that more effort was expended after the first individual of a target species was observed within a quadrat (M. Compton, OKNP, oral commun.). Future studies with blocknetted quadrats or repeat samples are needed to evaluate this effect empirically.

Flow velocity affects fish detection rates in many lotic ecosystem types (Gwinn and others, 2016), and our results showed this. However, flow velocity was found to be more important for BSD than CAD or KAD (table 3); this may be due to variation in mesohabitat use and body morphology between species. Specifically, pelagic stream fishes such as BSD typically exhibit laterally compressed body shapes that 


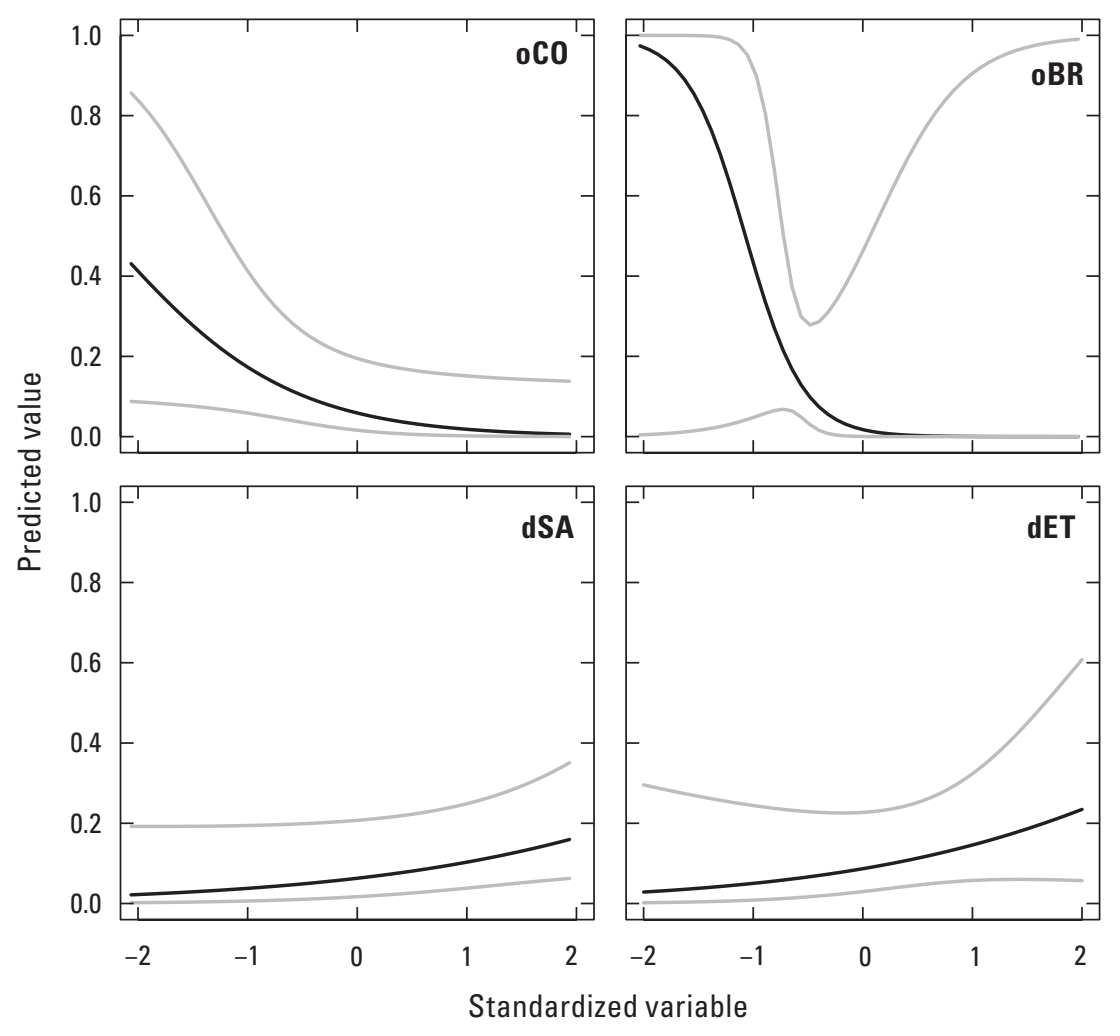

Figure 7. Kentucky arrow darter predicted occurrence and detection probabilities (black lines) and 95-percent confidence intervals (grey lines) for covariates in the top three models. Top three models are described in table 3. Covariates for occurrence ("o") and detection ("d") probabilities are defined in tables 1 and 2. others, 2010; Dean and others, 2019), but we could not directly evaluate this effect because conductivity was measured at the site level (that is, invariant at the quadrat level). Incorporation of temporal replicates would be necessary to quantify this effect (for example, Hayer and Irwin, 2008), but we are not confident that seasonal differences in conductivity downstream from mining operations in Appalachia (see Lindberg and others, 2011) would provide enough variation to permit modeling. Nonetheless, observed conductivity thresholds for electrofishing efficiency (Dean and others, 2019) exceed threshold effects of conductivity on stream fish populations and assemblages (Black and others, 2013b; Hitt and Chambers, 2014; Hitt and others, 2016); therefore, conductivity is expected to be more important for the occurrence process than the detection process for the focal species studied here.

This study was constrained by the spatial-replicate sampling design within sites. We assumed that the sampling process was independent among quadrats within a site, as required for statistical analysis. However, fish escapement from electrofishing may exceed the minimum quadrat spacing distance in this study (5 m), particularly within pool environ-

Table 5. Estimated detection probability and occurrence probability for top three occupancy models for blackside dace, Cumberland arrow darter, and Kentucky arrow darter.

[Models hold covariates at mean-effect levels and are listed in table 3. BSD, blackside dace; CAD, Cumberland arrow darter; KAD, Kentucky arrow darter; - , no data; $p$, detection probability; $p s i$, occurrence probability]

\begin{tabular}{|c|c|c|c|c|c|c|}
\hline \multirow[b]{2}{*}{ Model } & \multicolumn{2}{|c|}{ BSD } & \multicolumn{2}{|c|}{ CAD } & \multicolumn{2}{|c|}{ KAD } \\
\hline & $p$ & psi & $p$ & psi & $p$ & psi \\
\hline Naive & - & 0.100 & - & 0.167 & - & 0.071 \\
\hline 2 & 0.142 & 0.100 & 0.059 & 0.278 & 0.051 & 0.029 \\
\hline 3 & 0.170 & 0.094 & 0.062 & 0.271 & 0.071 & 0.075 \\
\hline
\end{tabular}

are expected to be more sensitive to changes in flow velocity than dorsally compressed benthic fishes such as CAD and KAD (Sagnes and Statzner, 2009). Similarly, Albanese and others (2007) report negative effects of flow velocity for detection of another rare, pelagic stream fish species in Appalachia (bluenose shiner). We also found that smaller substrates (that is, sand) increased detection probability for BSD and KAD (table 3), as reported by Albanese and others (2011).

Our inferences on conductivity were constrained by the sampling design. High conductivity levels can affect electrofishing efficiency (Hill and Willis, 1994; Hense and ments (for example, Hitt and others, in press). Kendall and White (2009) report that such non-independence in spatial replicates can bias species occupancy estimates. They further demonstrate that sampling quadrats with replacement can overcome this potential bias (Kendall and White, 2009). In our analysis this would require a randomization process to select spatial quadrats within study sites from which all spatial units could be selected in each sampling iteration (that is, sampling with replacement). Future research may benefit from this approach, as this could maintain the logistical benefits of 
spatial replicates (Srivathsa and others, 2018) by reallocating sampling effort with single site visits rather than requiring multiple site visits.

We found that imperfect detection is unlikely to explain the observed rarity of the focal species. Models accounting for detection of estimated BSD occupancy rates are similar to the observed proportion of occupied sites $(0.10)$, and the best-supported models for CAD and KAD increased expected occupancy by about 4 percent for each species (from 0.17 to 0.21 for CAD and from 0.07 to 0.11 for KAD). Our results therefore support prior research demonstrating the rarity of the focal species (Thomas, 2007, 2008; FWS, 2010a, 2015a, 2010b) and highlight the importance of their continued monitoring and assessment. A strength of this study is that sites were selected at random; therefore, results can inform expectations for species occupancy and detection across the study area.

\section{References Cited}

Albanese, B., Peterson, J.T., Freeman, B.J., and Weiler, D.A., 2007, Accounting for incomplete detection when estimating site occupancy of bluenose shiner (Pteronotropis welaka) in southwest Georgia: Southeastern Naturalist, v. 6, no. 4, p. 657-668.

Albanese, B., Owers, K.A., Weiler, D.A., and Pruitt, W., 2011, Estimating occupancy of rare fishes using surveys, with a comparison to backpack electrofishing: Southeastern Naturalist, v. 10, no. 3, p. 423-442.

Albanese, B., Litts, T., Camp, M., and Weiler, D.A., 2014, Using occupancy and species distribution models to assess the conservation status and habitat use of the goldline darter (Percina aurolineata) in Georgia, USA: Ecology Freshwater Fish, v. 23, no. 3, p. 347-359.

Bailey, L.L., MacKenzie, D.I., and Nichols, J.D., 2014, Advances and applications of occupancy models: Methods in Ecology and Evolution, v. 5, no. 12, p. 1269-1279.

Black, T., Jones, B.K., and Mattingly, H.T., 2013a, Development and validation of habitat models for the threatened blackside dace, Chrosomus cumberlandensis, at two spatial scales: Southeastern Naturalist, v. 12 (special issue 4), p. 27-48.

Black, T., Detar, J., and Mattingly, H.T., 2013b, Population densities of the threatened blackside dace, Chrosomus cumberlandensis, in Kentucky and Tennessee: Southeastern Naturalist, v. 12 (special issue 4), p. 6-26.
Blanton, R.E., Cashner, M.F., Thomas, M.R., Brandt, S.L., and Floyd, M.A., 2019, Increased habitat fragmentation leads to isolation among and low genetic diversity within populations of the imperiled Kentucky arrow darter (Etheostoma sagitta spilotum): Conservation Genetics, v. 20, no. 5, p. 1009-1022.

Burton, G.W., and Odum, E.P., 1945, The distribution of stream fish in the vicinity of Mountain Lake, Virginia: Ecology, v. 26, no. 2, p. 182-194.

Charbonnel, A., D’Amico, F.D., Besnard, A., Blanc, F., Buisson, L., Némoz, M., and Laffaille, P., 2014, Spatial replicates as an alternative to temporal replicates for occupancy modelling when surveys are based on linear features of the landscape: Journal of Applied Ecology, v. 51, p. 1425-1433.

Cormier, S.M., Wilkes, S.P., and Zheng, L., 2013, Relationship of land use and elevated ionic strength in Appalachian watersheds: Environmental Toxicology and Chemistry, v. 32, no. 2, p. 296-303.

Dean, J.C., Temple, A.J., and Smith, J.W., 2019, Output performance of U.S.-built backpack electrofishers: North American Journal of Fisheries Management, v. 39, no. 6, p. 1321-1328.

Eisenhour, D.J., and Strange, R.M., 1998, Threatened fishes of the world-Phoxinus cumberlandensis Starnes \& Starnes, 1978 (Cyprinidae) v. 51: Environmental Biology of Fishes, p. 140.

Etnier, D.A., and Starnes, W.C., 1993, The Fishes of Tennessee: Knoxville, Tennessee, University of Tennessee Press, 689 p.

Fagan, W.F., 2002, Connectivity, fragmentation, and extirpation risk in dendritic metapopulations: Ecology, v. 83, no. 12 , p. 3243-3249.

Fiske, I., and Chandler, R., 2011, Unmarked-An R package for fitting hierarchical models of wildlife occurrence and abundance: Journal of Statistical Software, v. 43, no. 10 , p. 1-23.

Green, R., and Young, R., 1993, Sampling to detect rare species: Ecological Applications, v. 3, no. 2, p. 351-356.

Gwinn, D.C., Beesley, L.S., Close, P., Gawne, B., and Davies, P.M., 2016, Imperfect detection and the determination of environmental flows for fish-Challenges, implications and solutions: Freshwater Biology, v. 61, no. 1, p. 172-180.

Hayer, C., and Irwin, E.R., 2008, Influence of gravel mining and other factors on detection probabilities of coastal plain fishes in the Mobile River basin, Alabama: Transactions of the American Fisheries Society, v. 137, no. 6, p. 1606-1620. 
Hense, Z., Martin, R.T., and Petty, J.T., 2010, Electrofishing capture efficiencies for common stream fish species to support watershed-scale studies in the central Appalachians: North American Journal of Fisheries Management, v. 30, no. 4, p. 1041-1050.

Hill, T.D., and Willis, D.W., 1994, Influence of water conductivity on pulsed $\mathrm{AC}$ and pulsed DC electrofishing catch rates for largemouth bass: North American Journal of Fisheries Management, v. 14, no. 1, p. 202-207.

Hitt, N.P., and Roberts, J.H., 2012, Hierarchical spatial structure of stream fish colonization and extinction: Oikos, v. 121 , no. 1 , p. $127-137$.

Hitt, N.P., and Chambers, D.B., 2014, Temporal changes in taxonomic and functional diversity of fish assemblages downstream from mountaintop mining: Freshwater Science, v. 33, no. 3, p. 915-926.

Hitt, N.P., Floyd, M., Compton, M., and McDonald, K., 2016, Threshold responses of blackside dace (Chrosomus cumberlandensis) and Kentucky arrow darter (Etheostoma spilotum) to stream conductivity: Southeastern Naturalist, v. 15, p, 41-60.

Hitt, N.P., Rogers, K.M., Snyder, C.D., and Dolloff, C.A. (in press) Comparison of underwater video with electrofishing and dive-counts for stream fish abundance estimation: Transactions of the American Fisheries Society.

Hopkins, R.L., II, and Roush, J.A., 2013, Effects of mountaintop mining on fish distributions in central Appalachia: Ecology Freshwater Fish, v. 22, no. 4, p. 578-586.

Kendall, W.L., and White, G.C., 2009, A cautionary note on substituting spatial subunits for repeated temporal sampling in studies of site occupancy: Journal of Applied Ecology, v. 46 , p. $1182-1188$.

Kuehne, R.A., and Bailey, R.M., 1961, Stream capture and the distribution of the percid fish Etheostoma sagitta, with geologic and taxonomic considerations: Copeia, v. 1961, no. 1, p. $1-8$.

Lindberg, T.T., Bernhardt, E.S., Bier, R., Helton, A.M., Merola, R.B., Vengosh, A., and DiGiulio, R.T., 2011, Cumulative impacts of mountaintop mining on an Appalachian watershed: Proceedings of the National Academy of Sciences of the United States of America, v. 108, no. 52, p. 20929-20934.

MacKenzie, D.L., Nichols, J.D., Lachman, G.B.G., Droege, S., Royle, J.A., and Langtimm, C.A., 2002, Estimating site occupancy rates when detection probabilities are less than one: Ecology, v. 83, no. 8, p. 2248-2255.
Mattingly, H.T., and Black, T.R., 2013, Nest association and reproductive microhabitat of the threatened blackside dace Chrosomus cumberlandensis: Southeastern Naturalist, v. 12 (special issue 4), p. 49-63.

Merovich, G.T., Hitt, N.P., Merriam, E., and Jones, J., in press, Response of aquatic life to coal mining in Appalachia, in Zipper, C., and Skousen, J., eds., chap. 12 of Appalachia's Coal-Mined Landscapes-Resources and Communities in a New Energy Era: New York, Springer Nature.

Merriam, E.R., Petty, J.T., Merovich, G.T., Fulton, J.B., and Strager, M.P., 2011, Additive effects of mining and residential development on stream conditions in a central Appalachian watershed: Journal of the North American Benthological Society, v. 30, no. 2, p. 399-418.

Moore, M.J., Hallerman, E.M., and Orth, D.J., 2017, Densities and population sizes of Clinch dace Chrosomus sp. cf. saylori in the upper Clinch River basin in Virginia: Copeia, v. 105 , no. 1 , p. $92-99$.

O'Bara, C.J., 1991, Current distribution and status of the upper Cumberland River johnny darter, Etheostoma nigrum susanae: Journal of the Tennessee Academy of Science, v. 66 , no. 1, p. $9-11$.

Palmer, M.A., Bernhardt, E.S., Schlesinger, W.H., Eshleman, K.N., Foufoula-Georgiou, E., Hendryx, M.S., Lemly, A.D., Likens, G.E., Loucks, O.L., Power, M.E., White, P.S., and Wilcock, P.R., 2010, Mountaintop mining consequences: Science, v. 327, no. 5962, p. 148-149.

Reynolds, J.B., and Kolz, A.L., 2012, Electrofishing, in Zale, A.V., Parrish, D.L., and Sutton, T.M., eds., Fisheries techniques, ( $3 \mathrm{~d}$ ed.): Bethesda, Md., American Fisheries Society, p. 305-361.

Royle, J.A., and Nichols, J.D., 2003, Estimating abundance from repeated presence-absence data or point counts: Ecology, v. 84, no. 3, p. 777-790.

Sagnes, P., and Statzner, B., 2009, Hydrodynamic abilities of riverine fish-A functional link between morphology and velocity use: Aquatic Living Resources, v. 22, no. 1, p. 79-91.

Schmidt, T.S., Clements, W.H., and Cade, B.S., 2012, Estimating risks to aquatic life using quantile regression: Freshwater Science, v. 31, no. 3, p. 709-723.

Sheldon, A.L., 1968, Species diversity and longitudinal succession in stream fishes: Ecology, v. 49, no. 2, p. 193-198.

Skelton, C.E., 2013, Distribution of blackside dace, Chrosomus cumberlandensis, in the upper Tennessee River drainage of Virginia: Southeastern Naturalist, v. 12 (special issue 4), p. 176-180. 
Starnes, W.C., and Starnes, L.B., 1978, A new cyprinid of the genus Phoxinus endemic to the upper Cumberland River drainage: Copeia, v. 1978, no. 3, p. 508-516.

Starnes, L.B., and Starnes, W.C., 1981, Biology of the blackside dace Phoxinus cumberlandensis: American Midland Naturalist, v. 106, no. 2, p. 360-371.

Srivathsa, A., Puri, M., Kumar, N.S., Jathanna, D., and Karanth, K.U., 2018, Substituting space for timeEmpirical evaluation of spatial replication as a surrogate for temporal replication in occupancy modelling: Journal of Applied Ecology, v. 55, no. 2, p. 754-765.

Thomas, M., 2007, Distribution and status of the Cumberland darter in the upper Cumberland River drainage, KentuckySection II of the Interim Annual Performance Report for State and Tribal Wildlife Grant-T-9-RSI-1 Ichthyofauna Resources of Kentucky: Frankfort, Kentucky, Fisheries Division, Kentucky Department of Fish and Wildlife Resources, $61 \mathrm{p}$.

Thomas, M., 2008, Distribution and status of the Kentucky Arrow Darter-Section I of the Interim Annual Performance Report for State and Tribal Wildlife Grant-T-9-RSI-1 Ichthyofauna Resources of Kentucky: Frankfort, Kentucky, Fisheries Division, Kentucky Department of Fish and Wildlife Resources, 9 p.

U.S. Environmental Protection Agency (EPA), 2011, A field-based aquatic life benchmark for conductivity in central Appalachian streams: Washington D.C., EPA/600/R- 10/023F.

U.S. Fish and Wildlife Service (FWS), 1987, Endangered and threatened wildlife and plants; determination of threatened species status for the blackside dace: Federal Register, v. 52, p. $22580-22585$.

U.S. Fish and Wildlife Service (FWS), 1988, Blackside dace recovery plan: Atlanta, Ga., U.S. Fish and Wildlife Service, $23 \mathrm{p}$.

U.S. Fish and Wildlife Service (FWS), 2010a, Endangered and threatened wildlife and plants; review of native species that are candidates for listing as endangered or threatened; annual notice of findings on resubmitted petitions; annual description of progress on listing actions; proposed rule: Federal Register, v. 75, p. 69222-69294.
U.S. Fish and Wildlife Service (FWS), 2010b, Endangered and threatened wildlife and plants; listing the Cumberland darter, rush darter, yellowcheek darter, chucky madtom, and laurel dace as endangered throughout their ranges: Federal Register, v. 75, p. 36035-36057.

U.S. Fish and Wildlife Service (FWS), 2011, Endangered and Threatened Wildlife and Plants; endangered status for the Cumberland darter, rush darter, yellowcheek darter, chucky madtom, and laurel dace: Federal Register, v. 76, p. $48722-48741$.

U.S. Fish and Wildlife Service (FWS), 2012, Endangered and threatened wildlife and plants; review of native species that are candidates for listing as endangered or threatened; annual notice of findings on resubmitted petitions; annual description of progress on listing actions: Federal Register, v. 77, p. 69994-70060.

U.S. Fish and Wildlife Service (FWS), 2015a, Blackside dace (Chrosomus cumberlandensis) 5-year review-summary and evaluation: Frankfort, Ky., U.S. Fish and Wildlife Service, $82 \mathrm{p}$.

U.S. Fish and Wildlife Service (FWS), 2015b, Endangered and threatened wildlife and plants; 12-month findings on petitions to list 19 species as endangered or threatened species: Federal Register, v. 80, p. 60834-60850.

U.S. Fish and Wildlife Service (FWS), 2016, Endangered and threatened wildlife and plants; threatened species status for Kentucky arrow darter with 4(d) rule: Federal Register, v. 81, p. $68963-68985$.

U.S. Fish and Wildlife Service (FWS), 2019, Recovery Plan for the Cumberland Darter (Etheostoma susanae): Atlanta, Ga., U.S. Fish and Wildlife Service, 9 p.

Vannote, R.L., Minshall, G.W., Cummins, K.W., Sedell, J.R., and Cushing, C.E., 1980, The river continuum concept: Canadian Journal of Fisheries and Aquatic Sciences, v. 37, no. 1, p. 130-137.

Wentworth, C., 1922, A scale of grade and class terms for clastic sediments: The Journal of Geology, v. 30, no. 5, p. 377-392.

Wickham, J., Homer, C., Vogelmann, J., McKerrow, A., Mueller, R., Herold, N., and Coulston, J., 2014, The MultiResolution Land Characteristics (MRLC) consortium-20 years of development and integration of USA national land cover data: Remote Sensing, v. 6, no. 8, p. 7424-7441. 
Occupancy of Rare Stream Fish in the Upper Cumberland and Kentucky River Basins

\section{Appendix 1}


Table 1.1. Sampling sites in the upper Cumberland River Basin and upper Kentucky River Basin.

[Site coordinates are given in decimal degrees. CU, Cumberland River Basin, n=120; KE, Kentucky River Basin, n=85. Fish and habitat sampling were coordinated by M. Compton (Office of Kentucky Nature Preserves) and M. Floyd (U.S. Fish and Wildlife Service)]

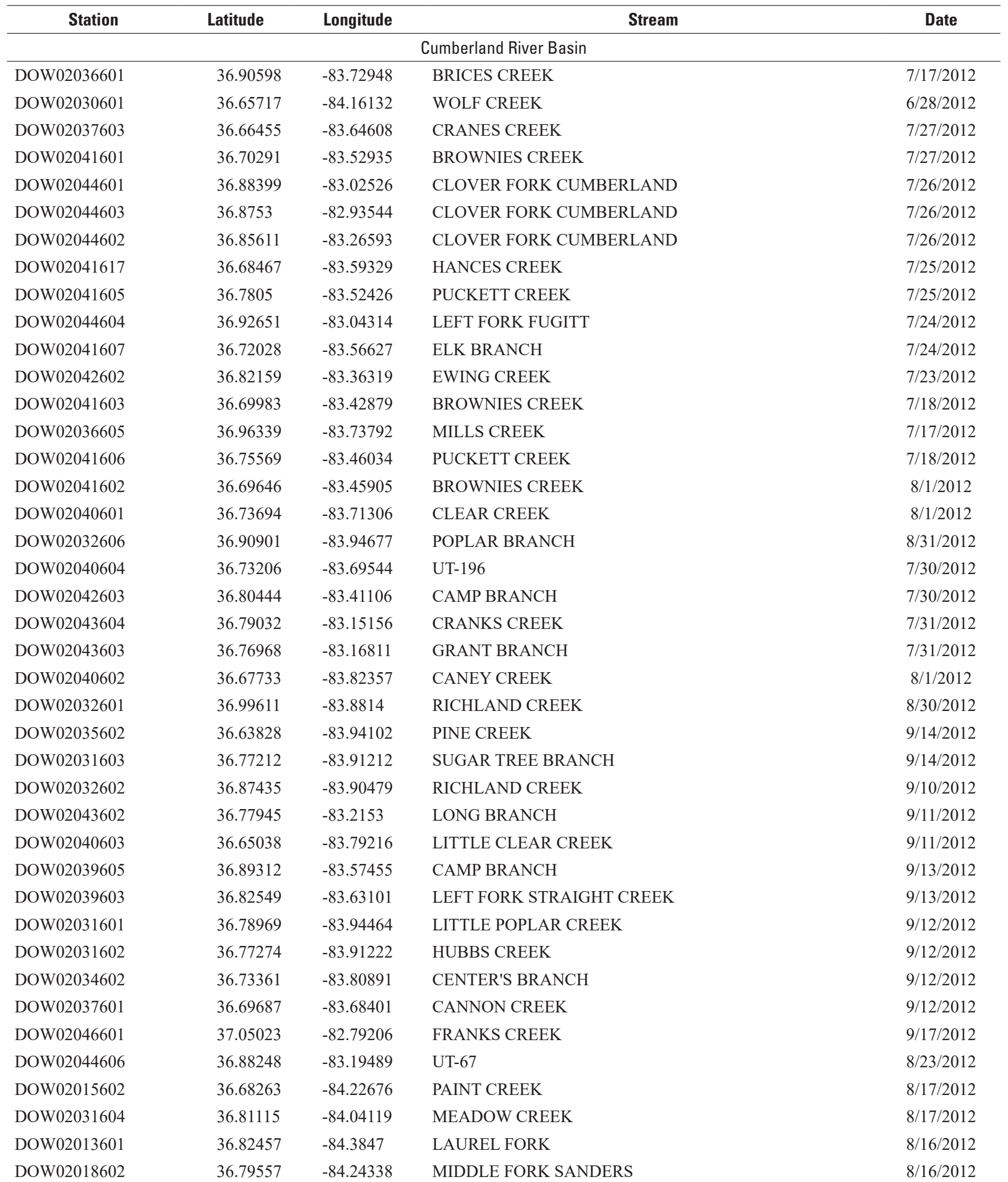


Table 1.1. Sampling sites in the upper Cumberland River Basin and upper Kentucky River Basin. -Continued

[Site coordinates are given in decimal degrees. CU, Cumberland River Basin, n=120; KE, Kentucky River Basin, $\mathrm{n}=85$. Fish and habitat sampling were coordinated by M. Compton (Office of Kentucky Nature Preserves) and M. Floyd (U.S. Fish and Wildlife Service)]

\begin{tabular}{|c|c|c|c|c|}
\hline Station & Latitude & Longitude & Stream & Date \\
\hline DOW02018601 & 36.76049 & -84.28849 & ARCHERS CREEK & $8 / 16 / 2012$ \\
\hline DOW02017601 & 36.81052 & -84.10201 & JACKS FORK & $8 / 15 / 2012$ \\
\hline DOW02031606 & 36.68153 & -83.92248 & POPLAR CREEK & $8 / 21 / 2012$ \\
\hline DOW02034601 & 36.72989 & -83.80033 & GREASY CREEK & $8 / 21 / 2012$ \\
\hline DOW02042601 & 36.8301 & -83.36998 & EWING CREEK & $8 / 22 / 2012$ \\
\hline DOW02043606 & 36.77204 & -83.24889 & LICK BRANCH & $8 / 23 / 2012$ \\
\hline DOW02042604 & 36.82518 & -83.41264 & TERRY FORK & $8 / 23 / 2012$ \\
\hline DOW02031608 & 36.88628 & -83.97385 & DEMPS HOLLOW & $8 / 27 / 2012$ \\
\hline DOW02031607 & 36.81023 & -84.06365 & UT-60 & $8 / 28 / 2012$ \\
\hline DOW02039602 & 36.80714 & -83.64741 & LEFT FORK STRAIGHT CREEK & $8 / 24 / 2012$ \\
\hline DOW02045601 & 36.87145 & -83.31072 & POOR FORK CUMBERLAND RIVER & $8 / 22 / 2012$ \\
\hline DOW02045602 & 36.88417 & -83.28529 & POOR FORK CUMBERLAND RIVER & $8 / 22 / 2012$ \\
\hline DOW02043601 & 36.77607 & -83.24201 & MARTINS FORK CUMBERLAND RIVER & $7 / 31 / 2012$ \\
\hline DOW02013602 & 36.81386 & -84.46021 & COGUR FORK & $7 / 23 / 2012$ \\
\hline DOW02014604 & 36.65868 & -84.40472 & CAT CREEK & $8 / 29 / 2012$ \\
\hline DOW02014603 & 36.66594 & -84.36974 & CLEAR CREEK & $8 / 29 / 2012$ \\
\hline DOW02015604 & 36.60236 & -84.31311 & ROCK CREEK & $8 / 15 / 2012$ \\
\hline DOW02037605 & 36.64899 & -83.57877 & SHILLALAH CREEK & $9 / 21 / 2012$ \\
\hline DOW02036604 & 36.90733 & -83.75924 & HALE FORK & $8 / 2 / 2012$ \\
\hline DOW02043605 & 36.68058 & -83.46429 & MARTINS FORK CUMBERLAND RIVER & $9 / 20 / 2012$ \\
\hline DOW02014602 & 36.76416 & -84.37695 & HENS NEST CREEK & $7 / 3 / 2012$ \\
\hline DOW02032605 & 37.03444 & -83.8686 & RICHLAND CREEK & $8 / 16 / 2012$ \\
\hline DOW02036606 & 36.93514 & -83.6008 & PAINT GAP BRANCH & $8 / 28 / 2012$ \\
\hline DOW02045603 & 37.06947 & -82.74626 & POOR FORK CUMBERLAND RIVER & $7 / 5 / 2012$ \\
\hline DOW02015605 & 36.62646 & -84.24312 & CRISCILLIS BRANCH & $9 / 11 / 2012$ \\
\hline DOW02014605 & 36.65385 & -84.42559 & PERKINS CREEK & $9 / 20 / 2012$ \\
\hline DOW02041604 & 36.70994 & -83.54005 & COAL STONE BRANCH & $9 / 20 / 2012$ \\
\hline DOW02035601 & 36.65200 & -83.87141 & LAUREL FORK & $9 / 19 / 2012$ \\
\hline DOW02015601 & 36.68715 & -84.27884 & JELLICO CREEK & $8 / 28 / 2012$ \\
\hline DOW02014601 & 36.78823 & -84.35911 & MARSH CREEK & $8 / 30 / 2012$ \\
\hline Primary 1 & 36.56581 & -83.81561 & SUGAN CREEK & $8 / 1 / 2015$ \\
\hline
\end{tabular}


Table 1.1. Sampling sites in the upper Cumberland River Basin and upper Kentucky River Basin. —Continued

[Site coordinates are given in decimal degrees. CU, Cumberland River Basin, n=120; KE, Kentucky River Basin, n=85. Fish and habitat sampling were coordinated by M. Compton (Office of Kentucky Nature Preserves) and M. Floyd (U.S. Fish and Wildlife Service)]

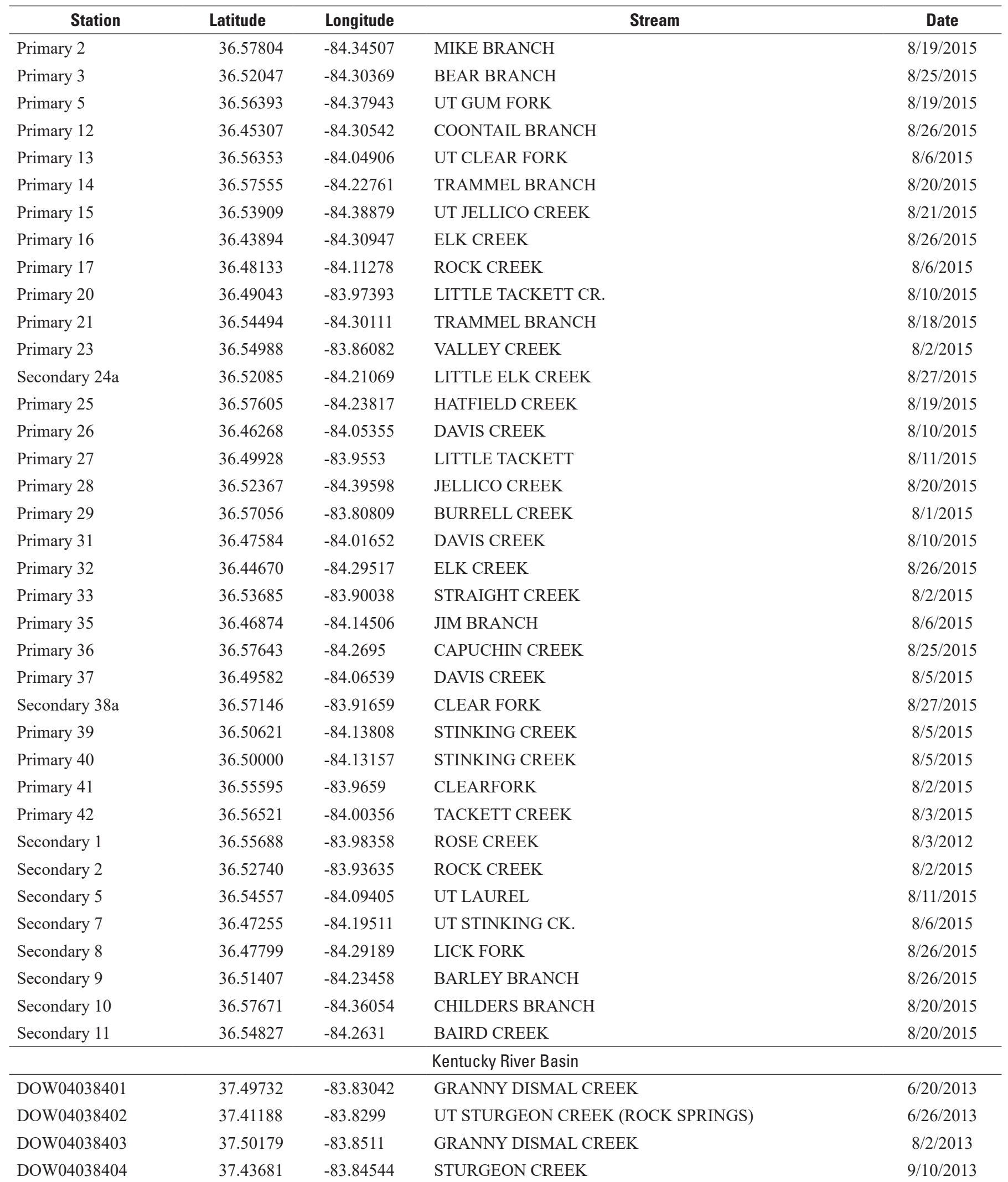


Table 1.1. Sampling sites in the upper Cumberland River Basin and upper Kentucky River Basin. —Continued

[Site coordinates are given in decimal degrees. CU, Cumberland River Basin, n=120; KE, Kentucky River Basin, n=85. Fish and habitat sampling were coordinated by M. Compton (Office of Kentucky Nature Preserves) and M. Floyd (U.S. Fish and Wildlife Service)]

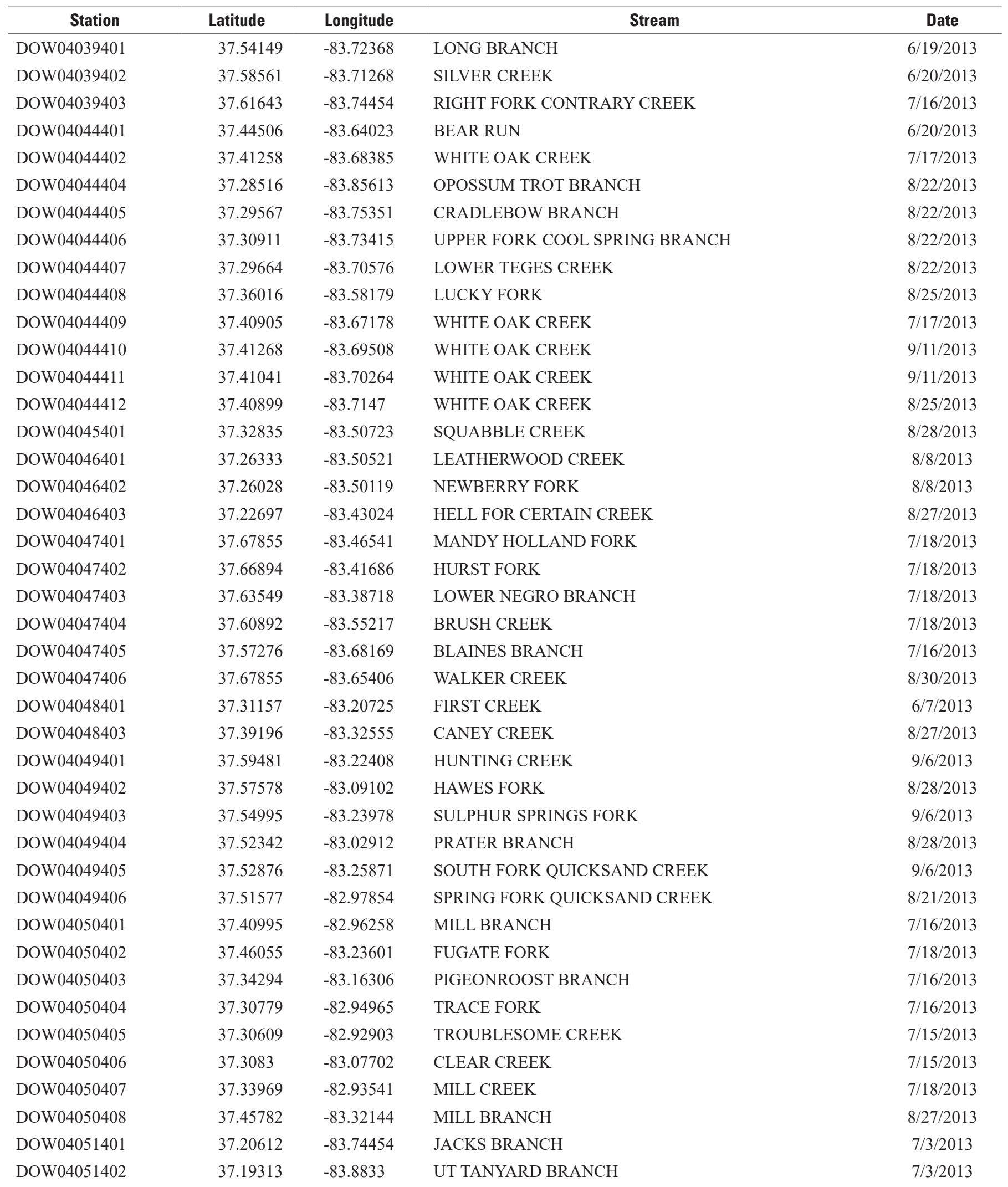


Table 1.1. Sampling sites in the upper Cumberland River Basin and upper Kentucky River Basin. —Continued

[Site coordinates are given in decimal degrees. CU, Cumberland River Basin, n=120; KE, Kentucky River Basin, n=85. Fish and habitat sampling were coordinated by M. Compton (Office of Kentucky Nature Preserves) and M. Floyd (U.S. Fish and Wildlife Service)]

\begin{tabular}{|c|c|c|c|c|}
\hline Station & Latitude & Longitude & Stream & Date \\
\hline DOW04051403 & 36.99118 & -83.79731 & HORN BRANCH & $7 / 2 / 2013$ \\
\hline DOW04051404 & 36.97298 & -83.78805 & SPRUCE PINE BRANCH & $7 / 2 / 2013$ \\
\hline DOW04051405 & 37.10643 & -83.84928 & EAST FORK PIGEON ROOST BRANCH & $7 / 3 / 2013$ \\
\hline DOW04051406 & 37.08695 & -83.70726 & SEVIER BRANCH & $7 / 25 / 2013$ \\
\hline DOW04051407 & 37.02646 & -83.84806 & BULL CREEK & $8 / 6 / 2013$ \\
\hline DOW04051408 & 37.0677 & -83.79964 & COLLINS FORK & $8 / 6 / 2013$ \\
\hline DOW04051409 & 37.10643 & -83.84928 & WEST FORK PIGEON ROOST BRANCH & 9/5/2013 \\
\hline DOW04051410 & 37.07975 & -83.73809 & SAPLINGS FORK & 9/5/2013 \\
\hline DOW04051411 & 37.12211 & -83.78849 & HORSE CREEK & 9/5/2013 \\
\hline DOW04052401 & 37.03937 & -83.47185 & BOWEN CREEK & $8 / 29 / 2013$ \\
\hline DOW04052402 & 37.07147 & -83.56499 & FLAT CREEK & $8 / 29 / 2013$ \\
\hline DOW04052403 & 37.1669 & -83.5146 & BOBS FORK & $8 / 29 / 2013$ \\
\hline DOW04052404 & 37.18257 & -83.49213 & BOBS FORK & $8 / 29 / 2013$ \\
\hline DOW04053401 & 37.16959 & -83.33263 & FLACKEY BRANCH & $9 / 5 / 2013$ \\
\hline DOW04054401 & 37.13542 & -83.33733 & HURRICANE CREEK & $7 / 25 / 2013$ \\
\hline DOW04054402 & 37.13655 & -83.39836 & SHORT CREEK & $7 / 25 / 2013$ \\
\hline DOW04054403 & 37.13503 & -83.41166 & SHORT CREEK & $7 / 25 / 2013$ \\
\hline DOW04054404 & 36.93154 & -83.30248 & RIGHT FORK BILL BRANCH & $8 / 1 / 2013$ \\
\hline DOW04054405 & 36.95212 & -83.4084 & BIG BRANCH & $8 / 1 / 2013$ \\
\hline DOW04054406 & 37.11005 & -83.38237 & MUNCY CREEK & $8 / 1 / 2013$ \\
\hline DOW04054407 & 37.12391 & -83.38228 & MUNCY CREEK & $8 / 1 / 2013$ \\
\hline DOW04054408 & 37.03643 & -83.41328 & MIDDLE FORK KENTUCKY RIVER & $8 / 6 / 2013$ \\
\hline DOW04054409 & 36.97415 & -83.40526 & BEECH FORK & $8 / 6 / 2013$ \\
\hline DOW04054410 & 37.05801 & -83.42224 & TRACE BRANCH & 9/4/2013 \\
\hline DOW04054411 & 37.00126 & -83.33668 & BRITTON BRANCH & $9 / 4 / 2013$ \\
\hline DOW04055401 & 37.09106 & -82.99763 & LINE FORK & 9/9/2013 \\
\hline DOW04055402 & 37.28816 & -83.15596 & LOTTS CREEK & 9/3/2013 \\
\hline DOW04055405 & 37.09267 & -82.98618 & WHITAKER BRANCH & 9/4/2013 \\
\hline DOW04055406 & 37.06433 & -82.96947 & BIG BRANCH & 9/4/2013 \\
\hline DOW04055407 & 37.21628 & -83.18648 & BUFFALO CREEK & $8 / 28 / 2013$ \\
\hline DOW04055408 & 37.22045 & -83.17941 & BUFFALO CREEK & $8 / 28 / 2013$ \\
\hline DOW04057401 & 37.22125 & -82.98826 & SMITH BRANCH & $6 / 27 / 2013$ \\
\hline DOW04057402 & 37.27342 & -82.84293 & MEADOW BRANCH & $7 / 18 / 2013$ \\
\hline DOW04057403 & 37.24020 & -82.92062 & LITTLE CARR FORK & 9/9/2013 \\
\hline DOW04059401 & 37.16956 & -82.90687 & BLAIR BRANCH & $6 / 27 / 2013$ \\
\hline DOW04059402 & 37.11942 & -82.79408 & CRAFTS COLLY CREEK & $6 / 26 / 2013$ \\
\hline DOW04059403 & 37.05655 & -82.91555 & KINGS CREEK & $6 / 26 / 2013$ \\
\hline DOW04059404 & 37.14162 & -82.96789 & ROCKHOUSE CREEK & $6 / 27 / 2013$ \\
\hline DOW04059405 & 37.21926 & -82.66298 & WRIGHT FORK & $6 / 26 / 2013$ \\
\hline
\end{tabular}


Table 1.2. Goodness-of-fit of the three best occupancy models for blackside dace, Cumberland arrow darter, and Kentucky arrow darter.

[BSD, blackside dace; CAD, Cumberland arrow darter; KAD, Kentucky arrow darter. Cells show the type-1 error rates from bootstrapped chi-squared tests (1,000 replicates). Small error rate values indicate inadequate model fit in this context. See table 3 for model summaries]

\begin{tabular}{lllll}
\hline & Model & BSD & CAD & KAD \\
\hline 1 & 0.106 & 0.637 & 0.533 \\
2 & 0.782 & 0.263 & 0.401 \\
3 & 0.681 & 0.470 & 0.347 \\
\hline
\end{tabular}


For additional information, contact:

Director, Leetown Science Center U.S. Geological Survey 11649 Leetown Road Kearneysville, WV 25430

Or visit our website at: https://usgs.gov/centers/lsc

Publishing support provided by the West Trenton Publishing Service Center 


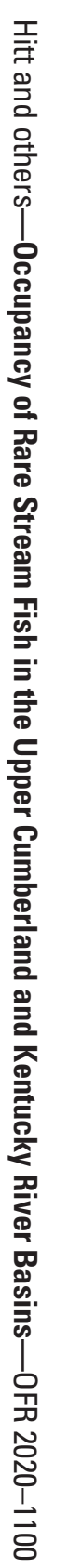

